\title{
Use of large-scale hydrological models to predict dam break-related impacts
}

\section{Utilização de modelos hidrológicos de larga escala na predição de impactos relacionados a rompimento de barragens}

\author{
Arthur da Fontoura Tschiedel ${ }^{1}$ (D), Rodrigo Cauduro Dias de Paiva ${ }^{1}$ (D) \& Fernando Mainardi Fan ${ }^{1}$ (D) \\ ${ }^{1}$ Universidade Federal do Rio Grande do Sul, Porto Alegre, RS, Brasil \\ E-mails: arthur.tschiedel@gmail.com (AFT), rodrigocdpaiva@gmail.com (RCDP), fernando.fan@ufrgs.br (FMF)
}

Received: August 29, 2019 - Revised: April 27, 2020 - Accepted: May 26, 2020

\begin{abstract}
In this research study, the MGB-IPH (acronym for Large Scale Model in Portuguese - Modelo de Grandes Bacias) was used to simulate the propagation of a dam breach hydrograph estimated from predictor equations for the Três Marias Hydropower Dam, considered one of the largest in South America. The results of the peak flow, peak time and flood spot were compared with results of the Hec-Ras 5.06 model, typically used for local-scale dam break studies. As for the extent of the flood, a hit rate of $84 \%$ and a median error of 2.1 meters deep, along $4,055 \mathrm{~km}^{2}$ of the flooded area downstream was obtained. Maximum errors of $13 \%$ were observed in the prediction of the peak flow and of $20 \%$ for the peak time in distant locations up to $526 \mathrm{~km}$ downstream from the dam, thus establishing itself within the limits of the typical uncertainties associated with dam break studies. Thus, the potential of using this type of approach in previous studies of large dam failures is explored, configuring this method as an alternative to the use of robust or simplified models for determining downstream areas potentially affected by these disasters.
\end{abstract}

Keywords: Large scale hydrological models; Dam break simulation; Inundation boundary.

\section{RESUMO}

Neste trabalho, foi utilizado o Modelo de Grandes Bacias (MGB-IPH) para simular a propagação de um hidrograma de ruptura estimado a partir de equações preditoras para a barragem da UHE Três Marias, considerada uma das maiores da América do Sul. Os resultados, quanto à vazão de pico, tempo de pico e mancha de inundação foram comparados com os resultados advindos do modelo Hec-Ras 5.06, tipicamente utilizado para estudos de rompimento de barragens em escala local. Quanto à extensão da mancha de inundação, obteve-se um índice de acerto de $84 \%$ e um erro mediano de 2,1 metros de profundidade, ao longo de $4.055 \mathrm{~km}^{2}$ de área inundada a jusante. Observaram-se erros máximos de 13\% na predição da vazão de pico e de $20 \%$ para o tempo de pico em locais distantes até $526 \mathrm{~km}$ a jusante da barragem, estabelecendo-se, portanto dentre os limites das incertezas típicas associadas a estudos de rompimento de barragens. Desta forma, o uso potencial deste tipo de abordagem em estudos prévios de rompimento de barragens é explorado, configurando-se este método como uma alternativa ao uso de modelos robustos ou simplificados para determinação de áreas de jusante potencialmente afetadas por estes desastres.

Palavras-chave: Modelos hidrológicos de larga escala; Simulação de rompimento de barragens; Manchas de inundação. 


\section{INTRODUCTION}

According to the International Commission on Large Dams (2018), more than 59 thousand large dams, for many different purposes, are observed worldwide. According to the Agência Nacional de Águas (2018), around 25 thousand dams (of all sizes) are observed on national soil. These structures, which are so important from the point of view of water resources management (Wood et al., 2011; Zarfl et al., 2015), are mostly used for irrigation and energy supply purposes (International Commission on Large Dams, 2018). On the other hand, the existence of dams is associated with potential risks that affect the resident populations downstream from these structures (Hariri-Ardebili, 2018; You et al., 2012), and embankment ruptures have been constantly observed throughout history (Zhang et al., 2016; Mao et al., 2017; Tschiedel et al., 2019).

The numerous historical disasters related to dam failures have led to the need for sector regulation, and in Brazil, the main legal tool is established based on the National Policy on Dam Safety (Brasil, 2010). This policy foresees, for dams with high or medium Associated Potential Damage - APD (excluding other situations), establishing Dam Safety Plans and consequent Emergency Action Plans - EAP (Peter, 2017; Agência Nacional de Águas, 2016b), which should be triggered in case of disasters.

In this case it is noted that in order to estimate the Associated Potential Damage of a dam (and consequently prioritize actions by regulatory agencies), there must be minimal knowledge about the potentially affected downstream zone in the case of a disaster (Brasil, 2012). And this estimate can be performed mostly in two ways: use of local hydrodynamic models and use of local simplified models.

The use of local hydrodynamic models such as Hec-Ras, Lisflood, Mike3 and FLDWV (George \& Nair, 2015; Patel et al., 2017) can be considered a robust approach as these models solve the Saint-Venant equations in forms 1D, 2D (Agência Nacional de Águas, 2016b), providing accurate information on peak flows, peak time, and extent of flooded areas at different sites downstream of the dams.

Regardless of the dimensionality considered, the approach associated with the use of these models to simulate dambreak wave can be considered local, specific and time-consuming (from the point of view of execution), associated with several input data specific to the region studied. Moreover, this approach can hardly be applied speedily on a large scale, ie for more than one dam or for more than one region, thus making it unfeasible to use for APD classification of dams.

In order to overcome this problem, simplified and more flexible methods have been developed in recent years to perform a preliminary estimate of flood spots associated with possible dam failures (Ferla et al., 2017). Among these methods, it is highlighted Melo et al. (2015), which presupposes only the use of topographic data associated with peak flow estimates obtained by using predictor equations (Froehlich, 1995a, 2008; Wang et al., 2018) to estimate downstream zones possibly reached in dambreak scenarios. In this sense, if on the one hand methods such as this are capable of quickly providing satisfactory preliminary results regarding the extent of the floodplain (Pereira et al., 2017; Gonçalves. 2018), without necessarily applying hydrodynamic models in the study area, on the other hand, its applicability remains, in most cases, punctual and restricted only to the area delimited for the study, rarely contemplating more than one dam located in the same area (Petry et al., 2018).

Therefore the need is observed for integrative assesssments in extensive and diverse regions regarding the failure of dams, together with the lack of a hydrodynamic method to predict these impacts, applicable in areas that transcend the local scale, ie considering the entire river basin of interest and considering more than one dam in a single study.

Wherefore, this work intends to explore a third alternative to the establishment of preliminary flood spots that may subsidize the calculation of the Associated Potential Damage of large dams. This alternative is based on the use of the flow propagation module of a Large Scale Hydrological Model (LSHM), constituted for a watershed of interest.

Outstanding among these LSHMs, which enable the provision of important information on water resources management (Emerton et al., 2016; Wood et al., 2011; Sood \& Smakhtin, 2015), is the MGB-IPH (Collischonn et al., 2007) that has already been applied to several Brazilian basins, and recently to South America (Siqueira et al., 2018a).

This model, in its most current version, allows representing the horizontal water balance processes in the watercourses and floodplains from the Inertial model (Pontes et al., 2017), which is a simplification of the Saint Venant equations used to several well-known LSHM like Camaflood (Yamazaki et al., 2013), Lisflood (Bates et al., 2010; Schumann et al., 2013) and Hymap (Getirana et al., 2017). The Inertial model neglects the term of advective inertia of the momentum conservation equation (Bates et al., 2010), generating greater computational efficiency as regards the representativeness of floodplains associated with good accuracy (Almeida \& Bates, 2013; Fan et al., 2014a).

It is also observed that the prediction of impacts associated with dam failures from the use of LSHMs has already been seen in Alves et al. (2019). In this work, MGB-IPH model (associated with the Inertial flow propagation module) it was applied in Uruguay River to estimate the damage associated with the cascade rupture of several dams present in the watershed, without any kind of validation. In this sense, even if the authors have not validated the results from a more consistent hydrodynamic model, we can see the beginning of the application of this approach in dam break analyses, and the error associated with its application should be quantified.

It is possible to observe, therefore, the need for APD estimates by regulatory agencies for a large number of dams on Brazilian soil, the limitations presented for the typically used approaches and also the need for knowledge of the error associated with the application of LSHMs in dam break analyses. So, aiming to better explore these problems, the work developed here verified the performance of the propagation module of the LSHM MGB IPH to predict variables related to the rupture of a large Brazilian dam. In this sense, once the potential use of this approach for a single dam has been tested and its limitations identified, it is understood as possible to perform further future tests applying this method to other situations involving different scales, regions and number of dams. 


\section{METHODOLOGY}

The methodology of this work is based on the comparison between the results obtained from the application of two distinct models to propagate an estimated rupture hydrograph for the chosen study area: The Três Marias HPP dam. Thus, the flow propagation module of the MGB-IPH model (Collischonn et al., 2007; Pontes et al., 2017), consolidated as a large-scale hydrologic-hydrodynamic simulation model and HEC-RAS 5.06 (US Army Corps of Engineers, 2014), considered as a hydrodynamic model, widely used in studies of dam failure, are applied to the study area.

The experiment in this study is consolidated as the simulation of the same rupture hydrograph in both models, observing the differences calculated as to the peak flow and peak time in 5 cross-sections, located at distances ranging from $131 \mathrm{~km}$ to $542 \mathrm{~km}$ downstream from the dam

The two models are different in their ways of considering not only flow propagation but also the topographic characteristics of the downstream valley. Due to these different characteristics, they are explored in the next topics.

\section{HEC-RAS 5.06}

Hec-Ras 5.06 is a non-commercial hydrodynamic model widely used for water resource management (Bhola et al., 2018), which allows performing one-dimensional, and/or two-dimensional flow simulations based on numerical solutions of the Saint Venant equations (US Army Corps of Engineers, 2016). In the unidimensional context, the equations of Saint Venant are presented as a set of two equations: the equation of continuity (1) and the equation of momentum (2), which together represent the physical laws that control the flow of a river dominated by flows in only one direction.

$$
\frac{\partial A}{\partial t}+\frac{\partial Q}{\partial x}-q_{l}=0
$$

$$
\frac{\partial Q}{\partial t}+\frac{\partial\left(Q^{2} / A\right)}{\partial x}+g A \frac{\partial h}{\partial x}=g A S_{0}-g A S_{f}
$$

This versatile model also includes simulations of sediment transport, water quality (Leon \& Goodell, 2016) and, as of 2014, dam rupture (US Army Corps of Engineers, 2014). Thus, from this year on, Hec-Ras has been widely used to predict the impact related to the collapse of these structures (Jung \& Kim, 2017; Tschiedel \& Paiva, 2018), both in 1 dimension and in 2 dimensions (US Army Corps of Engineers, 2016). The resolution of the Saint-Venant equations is obtained by using an implicit finite difference scheme, which is solved numerically based on the interaction of Newton-Raphson (US Army Corps of Engineers, 2016).

Substantial differences (Bhandari, 2017) or not (Gharbi et al., 2016; Shustikova et al., 2019; Liu et al., 2019) can be observed regarding the application of different dimensional approaches to flood simulations, so that their occurrence is directly related to the characteristics of the downstream valley (Lea et al., 2019). In general, when floodplains do not play a key role in downstream valley runoff (such as "V" shaped valleys), small differences in flow rates and peak times associated with $1 \mathrm{D}$ and 2D dam failure simulations can be observed, as well as differences in flooded areas in most cases (Ahmadian et al., 2018; Tschiedel, 2017), when the same physical processes of the SaintVenant equation are considered.

Thus, the way the floodplain is considered in the hydrodynamic model can directly influence the results obtained. In one-dimensional Hec-Ras, the Saint-Venant equations are solved not only for the main channel but for all cross-sections representing the topography of the simulated area, including, therefore, the floodplain. This means that the one-dimensional Hec-Ras is constituted from Active Plains. That is, the water moves not only in the main channel but also in the floodplains between two cross-sections (Figure 1), unlike MGB-IPH.

\section{MGB-IPH}

In its complete version, the MGB IPH (Collischonn et al., 2007; Pontes et al., 2017) is a large-scale distributed model that uses physical and conceptual equations to simulate hydrological and hydrodynamic processes that take place in a watershed, discretized in unit catchments associated with the units of homogeneous hydrological response, called HRU - Hydrological Response Unit. The model simulates Vertical Balance processes such as the water storage in the soil, evapotranspiration (by Penman Monteith), and the use of input data that vary spatially and temporally, such as rainfall and climate, interception, water infiltration in the soil, surface and subsurface runoff (Collischonn et al., 2007; Fleischmann et al., 2018; Pontes et al., 2017; Siqueira et al., 2018b).

The horizontal flow balance of the MGB-IPH is calculated by the propagation module, which calculates, for each unit catchment, the propagation of the volume existing in the upstream boundary condition for each time interval, in a system composed of main channel and a floodplain. In MGB-IPH, floodplains are considered passive, acting only as water reserve areas, without propagation between them, unlike Hec-Ras (Getirana \& Paiva, 2013; Siqueira et al., 2018b). Thus, the only way to propagate water to a downstream unit catchment, is from the main channel. In this sense, for a given time step in which the calculated water level for the river is such that it does not fit inside the river (Figure 2), the surplus volume is deposited in the floodplains (Figure 3), and is only available to be moved downstream when at a given time step the calculated water level for the main watercourse is less than the water level calculated for the floodplain in the previous time step (Figure 4).

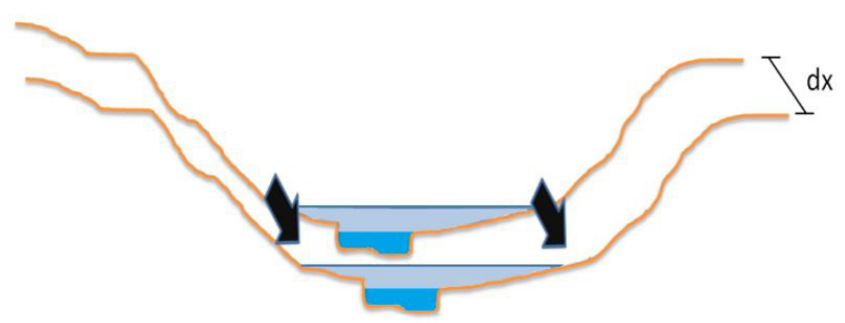

Figure 1. Behavior of Water Flow Between Cross-Sections in One-Dimensional Hec-Ras. Where dx is the Distance Between the Cross-Sections. 


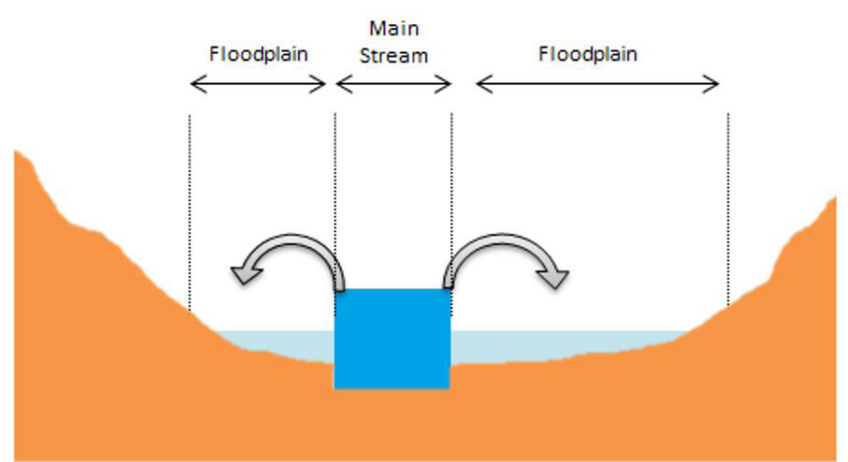

Figure 2. Volume calculation in unitcatchment.

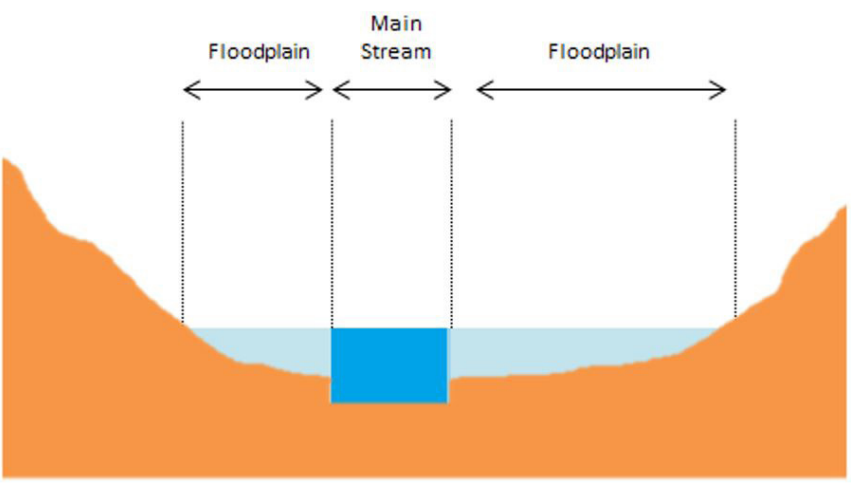

Figure 3. Updating the water table's elevation on the floodplain.

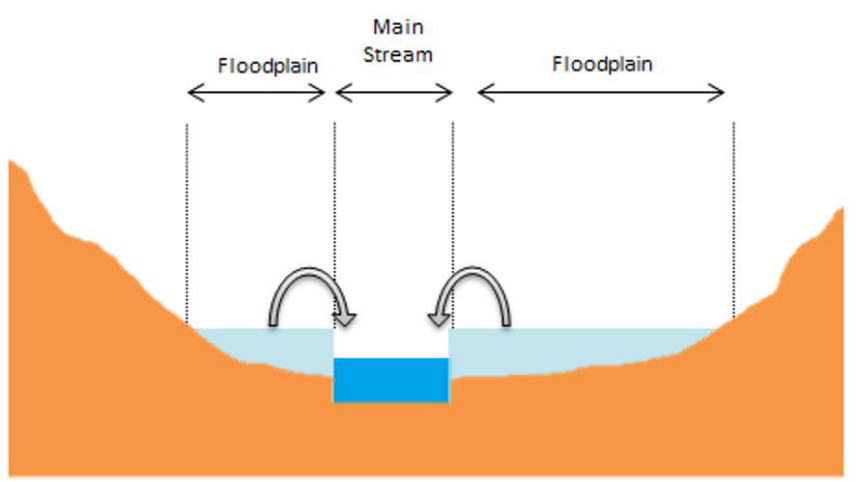

Figure 4. Contribution of the floodplain to the main channel.

The flow propagation can be calculated by the Muskingum-Cunge method (Collischonn et al., 2007; Fan et al., 2014b), or based on 1D hydrodynamic models (Fleischmann et al., 2018), simplified or not. 1D hydrodynamic models in the MGB have already been used considering both the complete form of the Saint-Venant equations (Paiva et al. 2011) and simplified forms (Fleischmann et al., 2018; Pontes et al., 2015, 2017; Siqueira et al., 2018a). Outstanding among the simplified forms is the Inertial Model (Bates et al., 2010), which considers, among others, the terms of Pressure and Local Inertia, that can thus provide a good representation of the downstream effects in rivers with a low slope (Fan et al., 2014a; Hoch et al., 2017; Pontes \& Collischonn, 2016). The flow propagation in the MGB-IPH, adopted for this work was simulated based on the Inertial Model (Pontes et al., 2017), established from a finite difference scheme (Siqueira et al., 2018b), so that the horizontal flow between the unit catchments occurs only by the main channel (with a rectangular section), whose widths and depths have previously been established from geomorphological relations (Paiva et al., 2013).

The choice regarding the use of the inertial model was based on the fact that it is currently available in the latest versions of the aforementioned model, besides the fact that these flow propagation scheme has greater numerical stability associated with shorter processing time, when compared to the use of the Saint Venant equations to simulate flow propagations (Fan et al., 2014a). In addition, other studies using simplified propagation models in hypothetical problems associated with dam ruptures have been previously conducted, showing potential good results, for certain flow conditions, when the Advective Inertia term, among others, are desconsidered (Martins et al., 2016; Liu et al., 2019).

It is also important to highlight that there are several solutions of equations of Saint Venant (beyond the inertial model), highlighting the kinematic wave models, gravitational model, diffusion model, non-inertial model among others. These solutions can be used to give quick answers, but it is detrimental in relation to the difficulty of its implementation when it is desired to represent detailed problems with real and complex geometry.

A complete description regarding the names of the simplified models based on the saint venant equations and their respective terms considered is presented in the Table 1 , that are a compilation based on Fan et al.(2014a) and Martins et al.(2016). Here it is important to hightlight that throughout the history of the development of simplifications of saint venant's equations, different names have been (and still are) assigned to equal sets of equations, in the same way that different sets of equations are presented with the same name in different studies. Thus, Table 1 does not seek to deeply exhaust this subject, but only to establish a basis for understanding these models within the scope of this work.

\section{Observed differences}

Two main differences are perceived regarding the propagation of the flow between the Hec-Ras and MGB models. The first is about the equation considered: While in Hec-Ras the complete equations of Saint-Venant (Hydrodynamic Model) are considered, in the MGB-IPH a simplification of these equations (Inertial Model) is considered, in which the term of advective inertia is suppressed (Table 1). The second is about flow propagation in the floodplain, which propagates flow in Hec-Ras but not in MGB-IPH.These two structural differences between the models may be highly relevant, when the results obtained from them are compared. On the other hand, it is possible to make Hec-Ras behave similarly to MGB in terms of the consideration of floodplains in the scope of propagation. This is possible by adopting infinite Manning coefficients for the external areas of the main watercourse in Hec-Ras (ie areas outside the banks), following an approach explored by Liu et al. (2019) or by considering ineffective areas in the model.

This type of approach adopted in Hec-Ras can, therefore, generate compatibility between both models, which allows evaluating the differences obtained only in the method of propagation of the main channel hydrograph (Hydrodynamic Model x Inertial Model) 
Table 1. Equations of Saint Venant and its simplifications.

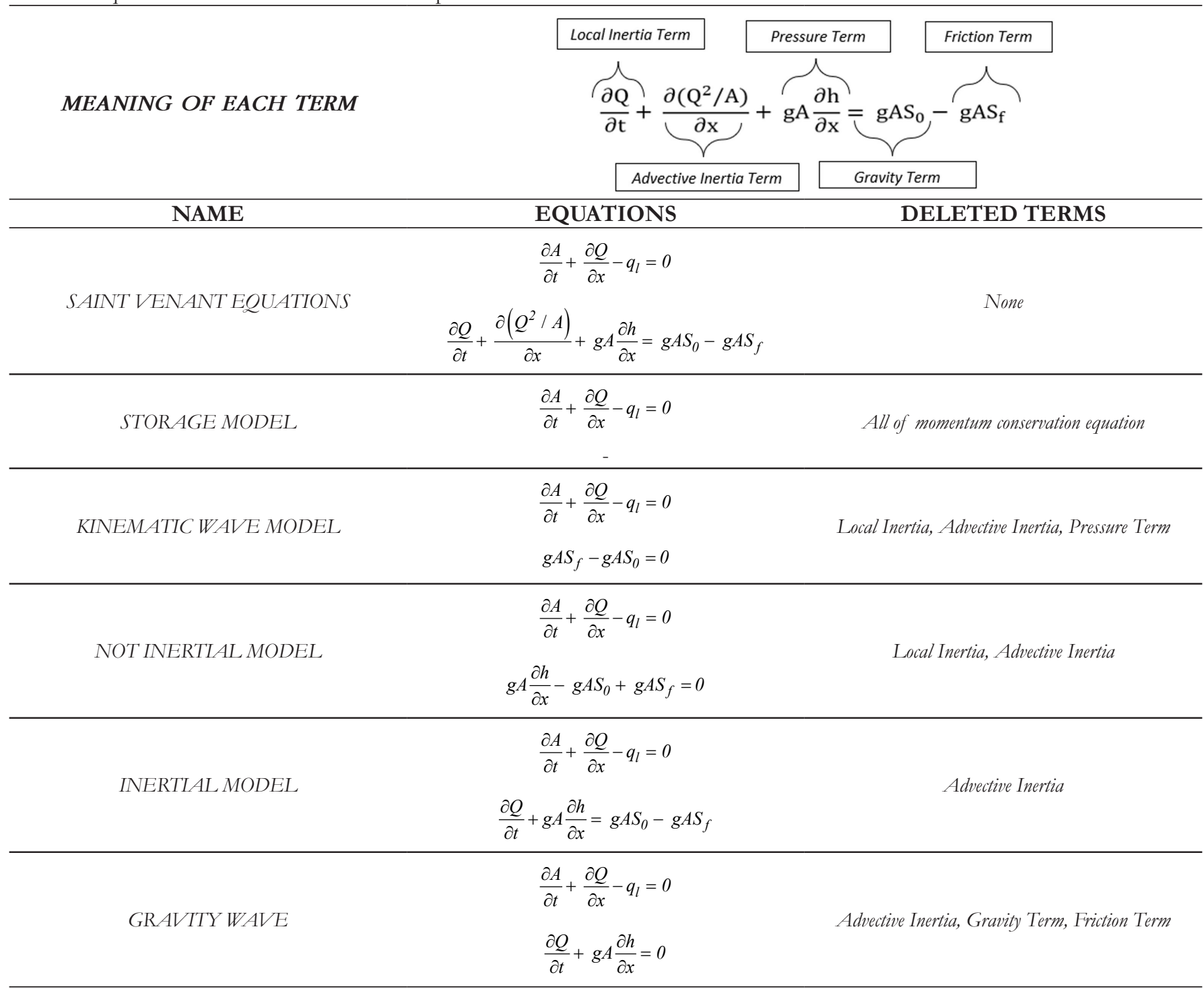

and the degree of representativeness of the topography (sections $\mathrm{x}$ unit catchments). Further details on how the rupture hydrograph was estimated for the study area are presented in the next item.

It is also worth noting that the Hec-Ras model is a local hydrodynamic model whose simulations typically does not represent vertical water balance processes, such as precipitation, infiltration and evapotranspiration. On the other hand, MGB-IPH represents these processes, which were deactivated in order to achieve full compatibility between the models. Thus, in this work an alternative version of the MGB-IPH was used in which the vertical soil water balance processes were disregarded, considering only the flow propagation module.

Therefore, we attempted to identify only the differences related to the consideration of topography by unit catchments and the use of the inertial method, to the detriment of the representation of topography by transversal sections and the use of the complete hydrodynamic model, respectively in MGB-IPH and Hec- Ras.

Finally, MGB-IPH for the case presented here was used based on an hourly discretization, similar to that observed in (Fleischmann et al., 2019a), which allows greater representativeness regarding the propagation of the estimated rupture hydrograph.

\section{Rupture hydrograph}

The characteristics of the rupture hydrograph formed due to the collapse of a dam are directly related to several aspects involved in this process, such as the type of breach considered, the width, height, gap, and formation time (US Army Corps of Engineers, 2014; Wang et al., 2018). Likewise, it is observed that the shape of the rupture hydrograph is also directly related to some geometric characteristics of both the dam and the reservoir (Froehlich, 1995a; Melo et al., 2015). In this sense, it is to be expected, for example, that the larger the reservoir, the greater the peak flow of the dam break hydrograph. Or, the greater the height of the dam, the higher the peak flow. Thus, in order to better understand these processes, over time, many researchers have dedicated efforts to studies that could correlate geometric 
variables of dams (such as reservoir volume, height and length of the dam) with peak flows and breach formation times observed in real failures (Froehlich, 2016; Pierce et al., 2010; Wang et al., 2018; Zhong et al., 2018).

In this sense, assuming that the peak time of the rupture hydrograph occurs at the moment the breach is formed completely (Ferla, 2018), it is possible to estimate flows and peak times from the use of prediction equations that take into account the geometric variables of the dams (Froehlich, 2016; Wang et al., 2018).

Thus, even with a high degree of variability and uncertainties (Ferla, 2018; Saraiva, 2014), the use of these equations for the prediction of flow and peak time may be feasible mainly for evaluations in sections distant from the dam. This is because the greater the distance between the section analyzed and the dam, the less influence is exerted by the different aspects related to the formation of the breach in variables such as peak flow and peak time. In this case, other input data such as Manning coefficient and reservoir volume will exert a greater influence on the prediction of variables such as peak time and peak flow (Collischonn \& Tucci, 1997; Kuhlkamp, 2016; Tschiedel \& Paiva, 2018).

The equations used for flow prediction and breach formation time (also considered as peak time) are highlighted in Equation 3, which was presented by Froehlich (1995b) and Equation 4, presented by Froehlich (2008), respectively. In these equations, $\mathrm{Tp}$ is the peak time (s); Qp is the peak flow $\left(\mathrm{m}^{3} / \mathrm{s}\right)$, $\mathrm{Vw}$ is the reservoir volume at the moment of rupture $\left(\mathrm{m}^{3}\right)$, $\mathrm{Hb}$ is the height of the water depth above the base of the breach formed $(\mathrm{m})$ and $\mathrm{g}$ is the acceleration of gravity.

$Q p=0.607 \times V_{w}^{0.295} x H_{w}^{1.24}$

$T_{p}=63.2 \sqrt{\frac{V_{w}}{g H_{b}^{2}}}$

To estimate a rupture hydrograph empirically, on the other hand, not only the Peak Flow and the Peak Time must be estimated, but the Hydrograph Base Time estimation is also of utmost importance, as can be observed in Figure 5

The resultant relationship of these observations is presented in Equation 5, where the base time can be obtained from the observations of Brasil (2005) and Mascarenhas (1990),

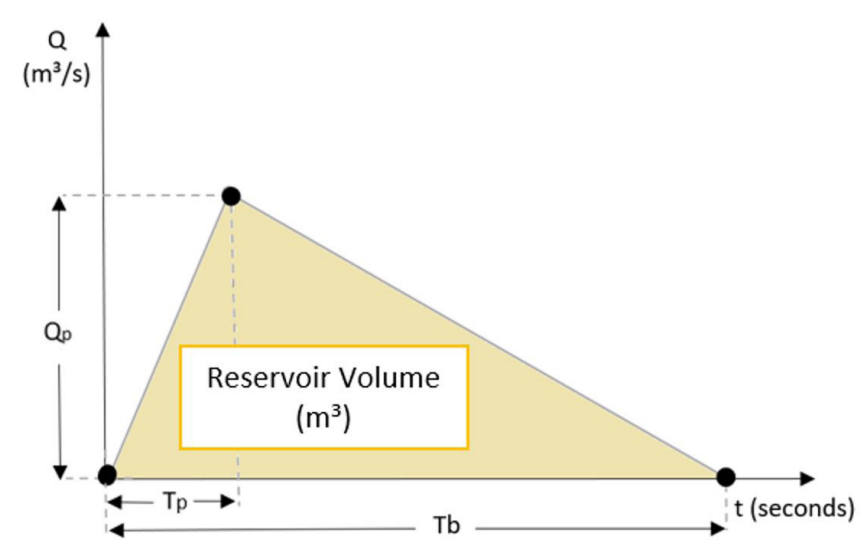

Figure 5. Rupture Hydrogram Scheme, Where Qp is the peak flow, $\mathrm{Tp}$ is the peak flow time and $\mathrm{Tb}$ is the base time. which assume a linear decrease of the maximum flow over time. In Equation 5, $\mathrm{Vr}$ is the reservoir volume $\left(\mathrm{m}^{3}\right)$, Qp is the peak flow $\left(\mathrm{m}^{3} / \mathrm{s}\right)$, and $\mathrm{Tb}$ is the base time (s).

$T_{b}=\frac{2 V_{r}}{Q_{p}}$

Equations 3, 4 and 5, if worked together, can be used to establish a hydrograph with hyperbolic decay (Barfield et al., 1981 apud Brasil, 2005; Lauriano, 2009), represented by Equation 6, where $\mathrm{k}$ is a decay coefficient that varies from 0 to 1 , which must be estimated considering the volume of the reservoir and the hydrograph obtained.

$Q_{(t)}=Q_{p}\left[\left(\frac{t}{T_{p}}\right) e^{\left(1-\frac{t}{T_{p}}\right)}\right]^{k}$

\section{STUDY AREA}

The study area of this work is a $567 \mathrm{~km}$ section of the São Francisco River, together with 4 tributaries, and their corresponding drainage areas. The mainstream (Rio São Francisco) starts at the Três Marias Hydroelectric Power Plant, owned by Companhia Energética de Minas Gerais - CEMIG, and ends (in the downstream portion) at the confluence with Carinhanha River, as presented in Figure 6. The study area of this work can therefore be compartmentalized into two different parts. The first one refers to the drainage area of the dam and the São Francisco river stretch, established in MGB-IPH Model $\left(51,300 \mathrm{~km}^{2}\right)$. The second refers specifically to the stream of the São Francisco River that were evaluated for the propagation of a rupture hydrograph potentially generated by the Três Marias HPP.

The choice of Três Marias HPP as a study area is due to two determining factors. The first of them is based on the relation of drainage area of the contributing basin $\left(\mathrm{km}^{2}\right)$ by reservoir volume $\left(\mathrm{km}^{3}\right)$, whose value is of the order of 2,500 , according to data obtained in Lehner et al. (2011). Other large dams located on Brazilian soil, such as Porto Primavera HPP or Itaipú HPP have values close to 30 thousand $\mathrm{km}^{2} / \mathrm{km}^{3}$. In addition to this relationship, another determining factor in the choice of Três Marias HPP as a study area is based on the geomorphological characteristics of the São Francisco River, which has a large partially rectilinear stretch downstream of the dam, with few large tributaries.

Thus, it is understood that the choice of this dam as a study area allows computational gain in the established LSHM, since among the input data there is the Digital Elevation Model (DEM) of the whole associated watershed, which is significantly smaller than other basins associated to dams with similar volume reservoirs.

The Três Marias Hydroelectric Power Plant was built between 1957 and 1962, for the purpose of generating energy, flow regulation, improving navigability, irrigation and industry development (Fan et al., 2014b; Operador Nacional do Sistema Elétrico, 2009). With an installed capacity of 396 MW, the hydroelectric power plant has an average outflow of $436 \mathrm{~m}^{3} / \mathrm{s}$ (Agência Nacional de Águas, 2019b) for the period between January 2010 and January 2018 (Figure 7). 

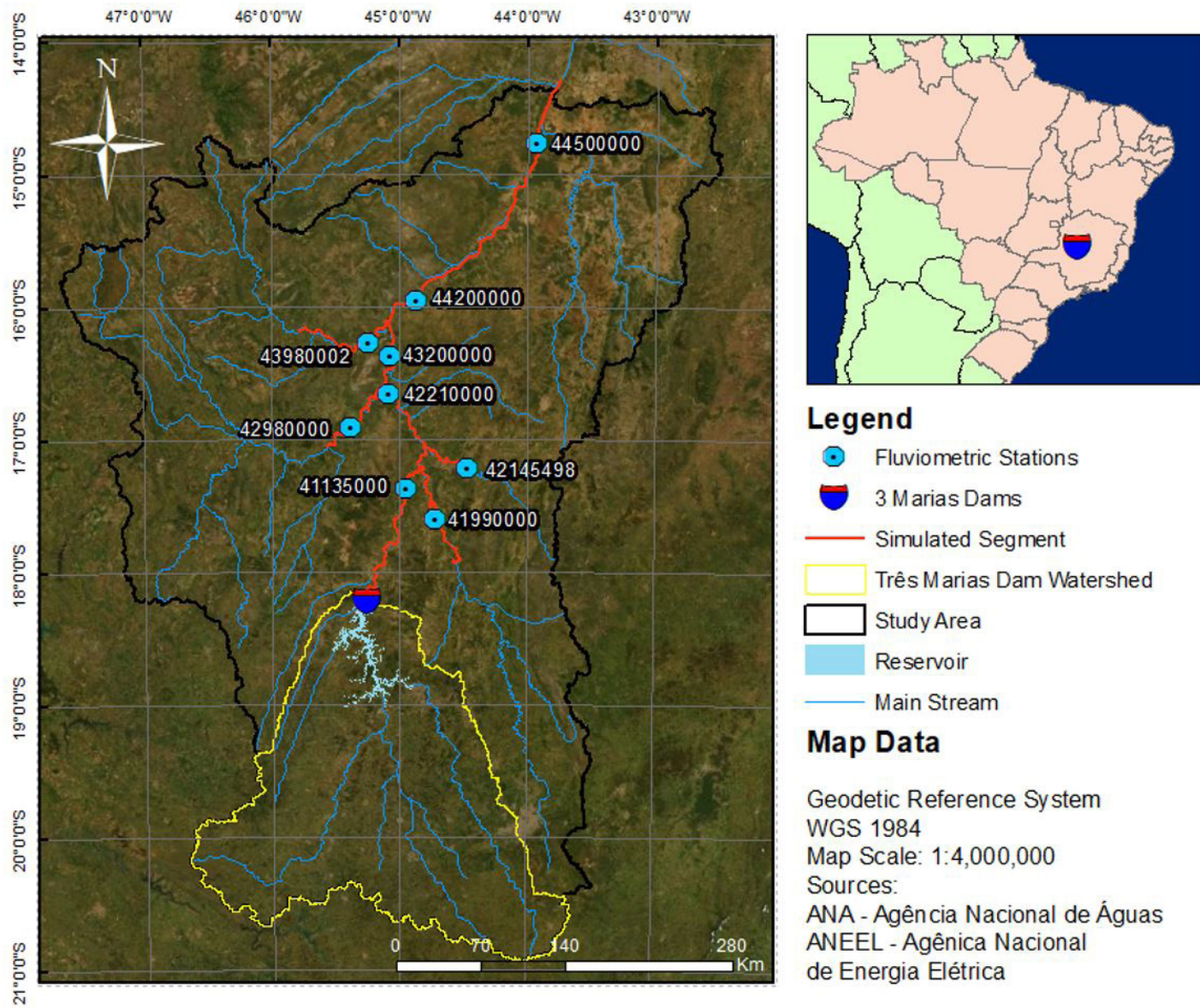

\section{Legend}

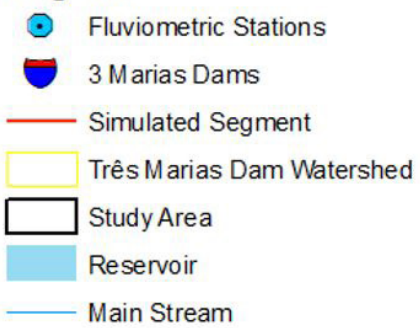

Map Data

Geodetic Reference System

WGS 1984

Map Scale: 1:4,000,000

Sources:

ANA - Agência Nacional de Águas

ANEEL - Agênica Nacional

de Energia Elétrica

Figure 6. Study Area.

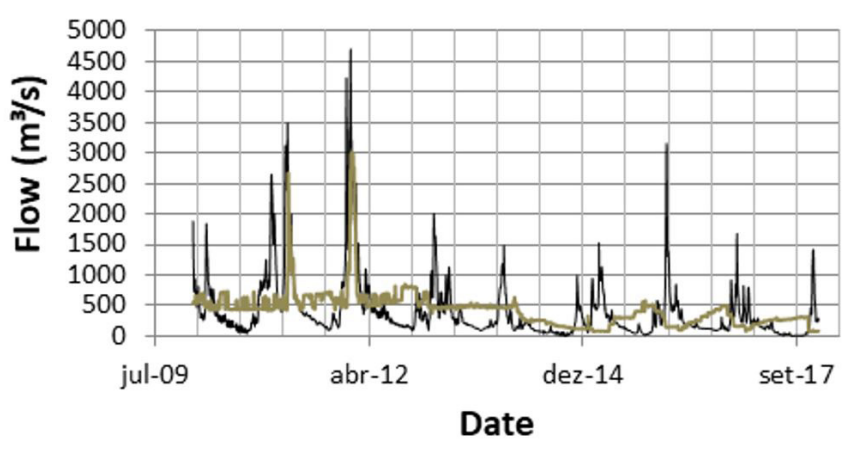

- Affluence $\left(\mathrm{m}^{3} / \mathrm{s}\right)$-Defluence $\left(\mathrm{m}^{3} / \mathrm{s}\right)$

Figure 7. Reservoir Inflows and Outflows.

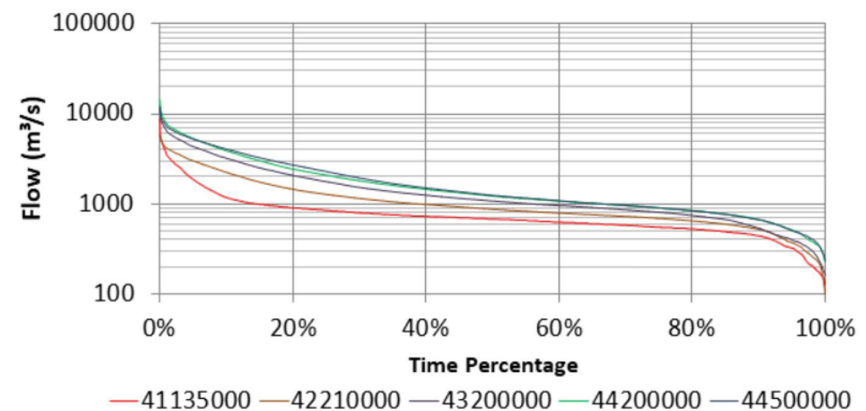

Figure 8. Flow Duration Curves of the São Francisco River Fluviometric Stations.
The dam, from the structural point of view, is an earth embankment, of the homogeneous type. With a length of 2,600 meters and a maximum height of 75 meters, from the foundation to the crest (Cruz, 2007), the dam is responsible for a flooded area that can reach up to approximately $1000 \mathrm{~km}^{2}$ depending on the operating water level (Bravo et al., 2006). This reservoir is one of the 10 largest in Brazil, a list that consists of reservoirs of plants such as Sobradinho HPP, Balbina HPP, Tucurui HPP, Itaipu HPP, among others (Agência Nacional de Águas, 2016a).

Likewise, the maximum volume of the Três Marias dam reservoir is also considered one of of the largest in the national territory. With approximately $19,528 \mathrm{hm}^{3}$ in the $572.5 \mathrm{~m}$ water surface elevation (Bravo et al., 2006), it is the sixth largest dam, surpassed only by Serra de Mesa HPP $\left(56,960 \mathrm{hm}^{3}\right)$, Tucuruí HPP $\left(50,280 \mathrm{hm}^{3}\right)$, Sobradinho HPP $\left(34,116 \mathrm{hm}^{3}\right)$, Furnas HPP $\left(24,881 \mathrm{hm}^{3}\right)$ and Ilha Solteira HPP, with $22,273 \mathrm{hm}^{3}$ (Agência Nacional de Águas, 2016a).

The downstream section of the study area, related to the $567 \mathrm{~km}$ of Rio São Francisco shown in Figure 6, is monitored by 5 fluviometric stations with an extended period of observation, which allows characterizing this section hydrologically. Thus, it is possible to visualize, in Figure 8, that the Pirapora Barreiro fluviometric station (41135000), the one closest to the Três Marias HPP dam (Figure 6), presents average flows of about $750 \mathrm{~m}^{3} / \mathrm{s}$ for the period between 1968 and 2016, while the Manga fluvial station (44500000), the farthest from Três Marias HPP, has an average flow rate of $1859 \mathrm{~m}^{3} / \mathrm{s}$. 
It is also interesting to note that, for the mainstream of the São Francisco River, the maximum flows observed in the aforementioned stations vary from about $8890 \mathrm{~m}^{3} / \mathrm{s}$, for station 41135000 to $11790 \mathrm{~m}^{3} / \mathrm{s}$, for Station 44500000 (Figure 9). In the same way that the fluviometric stations existing along the stretch of the São Francisco River were characterized, there was also the fluviometric characterization of some of the affluent rivers of this watercourse (also presented in Figure 6). Thus, the mean flows in stations 42145498, 41990000, 4298000 and 43980002 were obtained in order to compose the boundary conditions of the simulations performed.

\section{Input data and boundary conditions}

The input data used in both models relate mainly to the topographic and topobathymetric representation of the region, as well as to the Manning coefficients adopted for both the main channel $\left(0.03 \mathrm{sm}^{-1 / 3}\right.$ for both models $)$ and for the plains $\left(10 \mathrm{sm}^{-1 / 3}\right.$ in Hec-Ras and not applicable for MGB-IPH). The boundary conditions, on the other hand, are related to the flows adopted in the limits of the amount of the simulated stretches and to the considerations regarding the downstream limit, in both models.

The topobathymetric characterization of the region initially passes through the definition of average widths and depths of the watercourses, correlated with the amount of drainage area of each section of interest. This type of information is typically used in Large-Scale Hydrological Models (Paiva et al., 2013; Yan et al., 2015), which approximate the bathymetry of watercourses from rectangular channels.
Thus, the bathymetric profiles were consulted for a large number of fluviometric stations in the study area (Agência Nacional de Águas, 2019c), which were used to establish depths and rectangular widths for each section, considering the wet area and the average height observed in February 2000. This period was chosen to measure the region's watercourse water surface elevation, since it is concomitant with the period of overflight in the center-west region of Brazil (Seal \& Rogez, 2000) of the Shuttle Radar Topography Mission, which resulted in the SRTM global Digital Elevation Model (DEM) with 30 m of spatial resolution (Farr et al., 2007) and up to $6.2 \mathrm{~m}$ of absolute error for South America (Rodriguez et al., 2006). This DEM gave rise to the product used to represent the topography of the study area, which is a resampling of this DEM to a spatial resolution of $60 \mathrm{~m}$ and was intended to increase the computational gain in the simulations (according to techniques observed in studies such as Benas et al., 2014; Mason et al., 2016 and Fleischmann et al., 2019b). For this reason, the average depth in each section was established from the level observed on the same day the topographical data were obtained, resulting in greater compatibility between both items of information.

In addition, to establish the width of the watercourses as a function of the drainage area, virtual sections were also drawn along the basin's watercourses, using a satellite image to estimate widths for each section.

Finally, the knowledge of depths, widths and drainage area of each section evaluated, facilitated the formatting of geomorphological regression curves for these variables, presented in Figure 10.

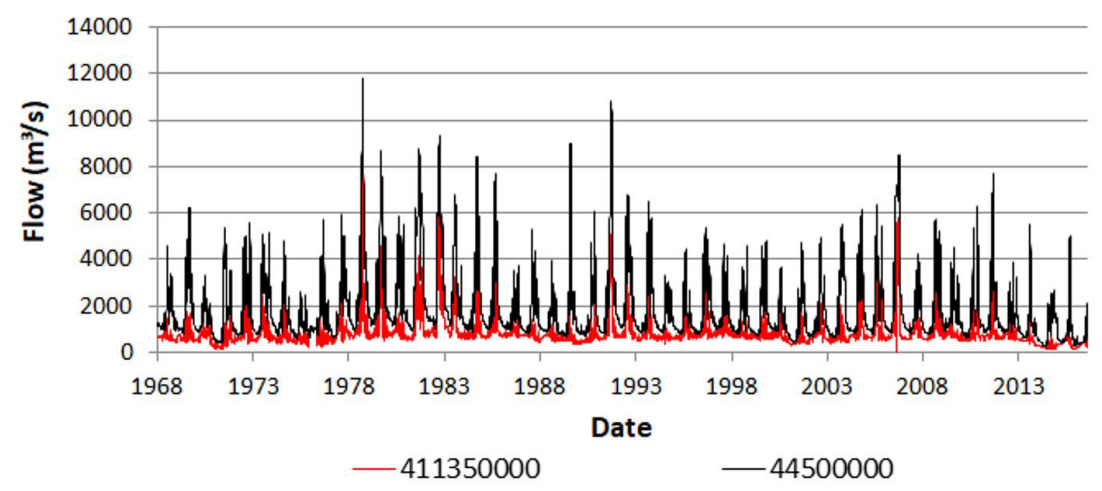

Figure 9. Characterization of the Downstream segment.

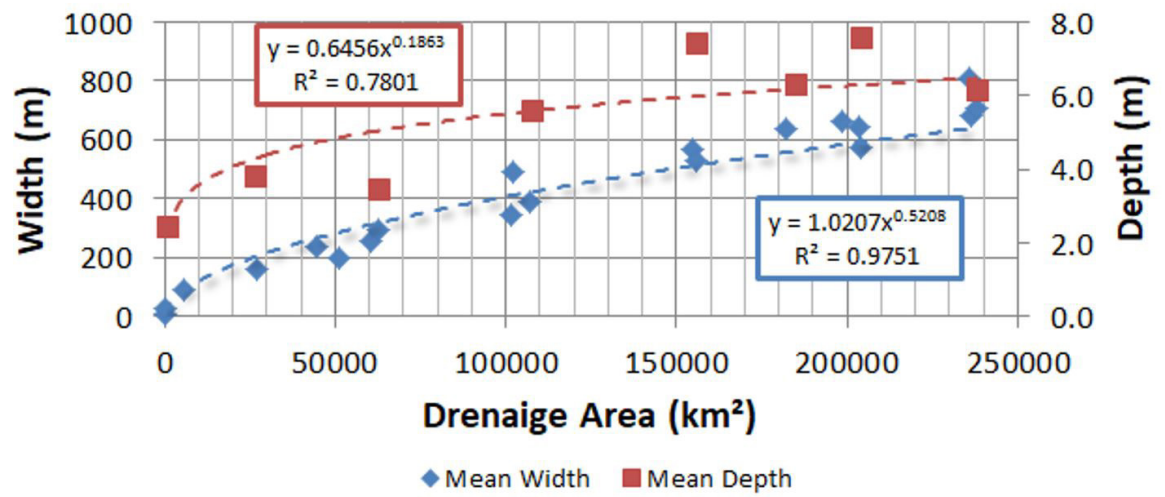

Figure 10. Geomorphological Relations in Downstream Segment. 
The inclusion of bathymetric information on the main watercourses in the topography was therefore based on the use of the geomorphological curve for depth (Figure 10), with this information being used to "burn" the São Francisco River and the 4 main tributaries in the SRTM DEM re-sampled to $60 \mathrm{~m}$, considering as a water extension the product provided by Agência Nacional de Águas (2019a). This procedure, which is a common technique for correcting surface drainage patterns (such as stroke and depth) derived from digital elevation models (Lindsay, 2016; Wang et al., 2019) generated a burned topographic product that was used to create hypsometric curves that relate the dimension to the volume stored in each unit catchment in the MGB IPH model. Likewise, the representation of the topography in the Hec-Ras model was carried out by using this burned DEM with a 60-meter resolution.

To illustrate the differences, in Figure 11 both topographies are presented together with the cross-sections estimated for Station 43200000 , as well as with the hypsometric curve generated for the unit catchment which is the said station considering the burned DEM. It is emphasized that in this figure it is possible to perceive the limits of the width of the watercourse with certain precision.

The widths of the São Francisco River were defined in each section of Hec Ras by the visualization of the boundaries imposed by the topography of the DEM itself of 60 meters, burned. It should be pointed out that this accurate representation of the width of the watercourses is not observed in the MGB-IPH model, where the width of the watercourse associated with each unit catchment (discretized for every $10 \mathrm{~km}$ of main river) is typically defined based on the geomorphological relationships calculated for the study area (Figure 10).

Aiming for greater representativeness between both models for the average width of the watercourses, for each unit catchment associated with the São Francisco River, the geomorphological relations for the width were replaced by an "average effective width", calculated from the average length of the river and water area of the São Francisco River within each unit catchment. From the division of the water extending (Agência Nacional de Águas, 2019a) along the length of the São Francisco River, in each unit catchment, a more representative "average effective width" for each stretch of river was obtained.

The Upstream Boundary Conditions (UBCs) and the Downstream Boundary Conditions (DBC) used for both models were exactly the same, adopting 5 different hydrograms for each of the 5 UBCs and a normal slope for the single DBC of each model. The UBCs, with the exception of the rupture hydrograph located at the Três Marias HPP, refer to the mean flow rates measured in the fluviometric stations 42145498, 41990000, 4298000 and 43980002, previously presented in Figure 6, respectively, for each tributary segment. For DBC, a value of $0.00005 \mathrm{~m} / \mathrm{m}$ was adopted, which refers to the average slope observed in the last $100 \mathrm{~km}$ of the simulated section.

Regarding the Rupture Hydrograph for the main UBC, this was defined using the equations previously presented, estimating a peak flow of about $140,000 \mathrm{~m}^{3} / \mathrm{s}$, associated with an estimated reservoir emptying time of approximately 5 days and at a peak time of about 10 hours.

\section{Evaluation methods}

The evaluative metrics used in this work are configured as the direct comparison between the peak and peak time flows for the region of the 5 fluviometric stations found along the São Francisco River, shown previously in Figure 6, distant approximately 131, 246, 287, 352 and $542 \mathrm{~km}$ from the dam site.
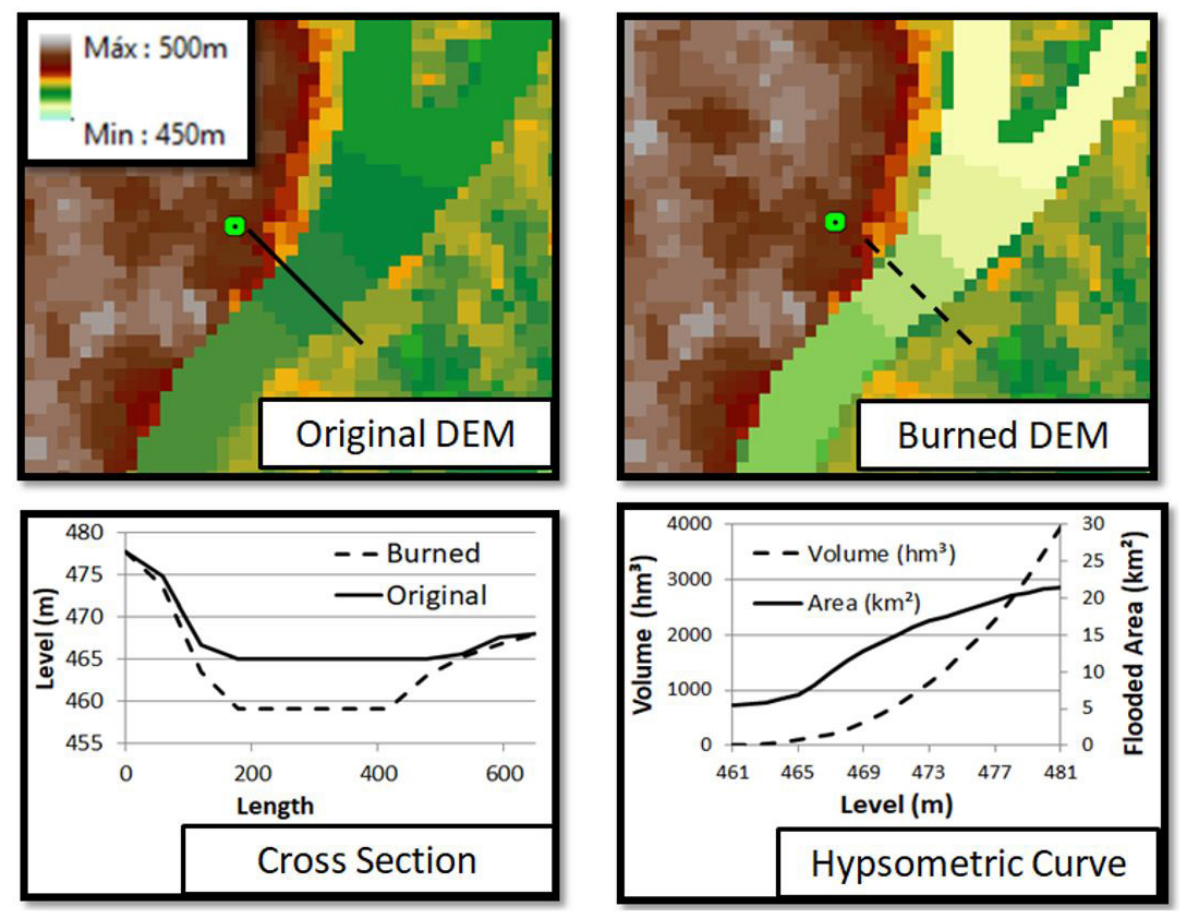

Figure 11. Differences between the original Topobathymetry and tuning for Station section 43200000. 
In addition to these metrics, we also compared flood spots generated by MGB and Hec-Ras from the use of the Critical Success Index (Bates et al., 2018; Fleischmann et al., 2019b; Hoch et al., 2017).

This index is calculated as shown in Equation 7, where $\mathrm{A}$ and $\mathrm{B}$ are the flood spots simulated respectively by Hec-Ras and MGB-IPH. The value of $\mathrm{F}$ varies from $0 \%$ to $100 \%$, so that $100 \%$ reflects the perfect coupling between the two spots, occurring when the sum between the areas not flooded by both with the sum of the flooded areas is equal to the area of the union between the two spots.

$$
F=100 \% x(A \cap B) /(A \cup B)
$$

As for the evaluation of the flood spot extension, a normalized depth error map was generated pixel by pixel, made from the subtraction of the depth verified in each pixel flooded by both models. Equation 8 shows this relationship.

$$
E p=\sqrt{\left(\operatorname{Prof}_{\mathrm{Hec}}-\operatorname{Prof}_{M G B I P H}\right)^{2}}
$$

where Prof $_{\mathrm{Hec}}$ is the depth verified from the application of the Hec-Ras model; Prof ${ }_{\mathrm{MGBIPH}}$ is the depth verified from the application of the MGB-IPH model; and Ep is the depth error given in meters.

This map was later evaluated considering the magnitude of the estimated pixel-to-pixel errors in relation to the reference depths obtained from the Hec-Ras model.

\section{RESULTS}

In general, low-magnitude differences are observed when comparing the Hec-Ras model and the MGB-IPH model for the peak time and peak flow variables. The differences obtained in the section located $131 \mathrm{~km}$ downstream from the dam (Figure 12) are about $13 \%$ for peak flow $\left(82211 \mathrm{~m}^{3} / \mathrm{s}\right.$ versus $\left.72834 \mathrm{~m}^{3} / \mathrm{s}\right)$ and about $-8 \%$ (2 days versus 1.83 days) for the peak time, showing an underestimation of the peak flow in the MGB model associated with a peak wave delay.

This behavior of the propagated flood wave changed as it moved downstream, observing an advance of the arrival of the hydrogram simulated by the MGB-IPH model associated with an overestimation of the peak flow, as can be observed in the figures $246 \mathrm{~km}$ downstream from the dam (Figure 13), $287 \mathrm{~km}$ (Figure 14), $352 \mathrm{~km}$ (Figure 15) and $542 \mathrm{~km}$ (Figure 16). In these figures, "Hec Flow" represents the results obtained by the Hec Ras model and "MGB Flow" represents the results obtained by the MGB model.

As presented in Table 2, the use of the MGB-IPH model to propagate dam rupture hydrograms to the study area presented the highest error relative to the peak flow for the first section analyzed (located at a distance of $131 \mathrm{~km}$ downstream from the dam). As this wave propagated downstream, errors in this parameter decreased in magnitude, ranging from $-7 \%$ to $+5 \%$ in relation to the reference simulation. The opposite behavior is observed in peak time.

In this sense, the further the section, the greater these errors, which may be associated with differences of about $20 \%$ in localized sections at distances of 352 and $542 \mathrm{~km}$ downstream from the dam. On the other hand, these errors are in favor of safety, since they are associated with the advance of the flood peak in the MGB-IPH. In this sense, the prediction of the arrival time of the peak flow can be advanced by up to 2 days, in a universe of approximately 13 , if the MGB-IPH model is used for this purpose (Table 2).

These differences observed in the evaluated parameters (which are associated only with the difference between the propagation models used and the structural and topological

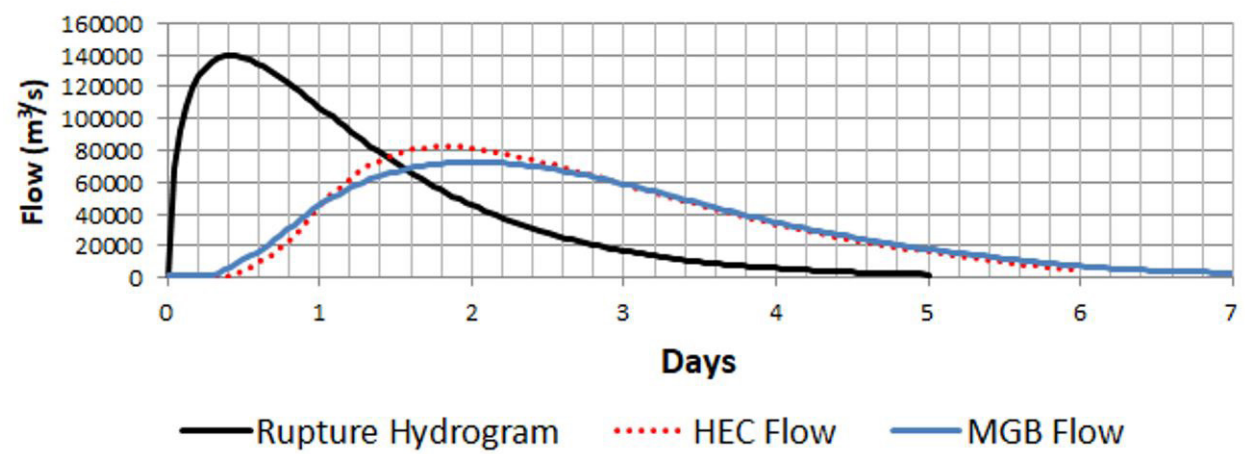

Figure 12. Hydrograms $131 \mathrm{~km}$ downstream from the dam (Station 411350000).

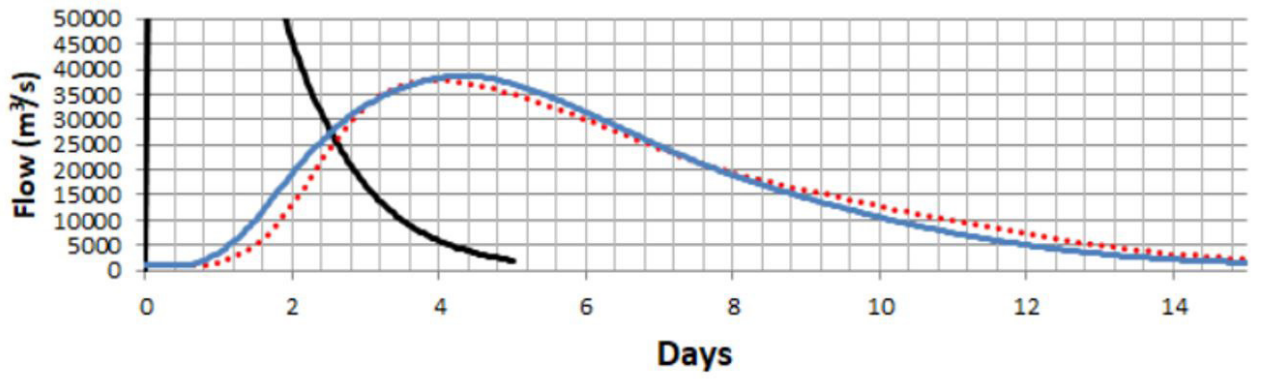

-Rupture Hydrogram ….. HEC Flow —MGB Flow

Figure 13. Hydrograms $246 \mathrm{~km}$ downstream from the dam (Station 42210000). 


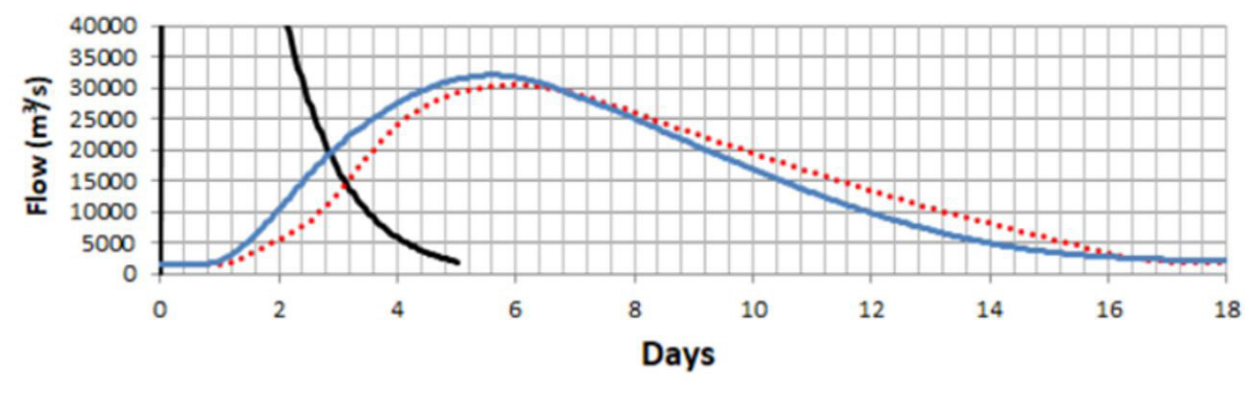

\section{—Rupture Hydrogram ….. HEC Flow - MGB Flow}

Figure 14. Hydrograms $287 \mathrm{~km}$ downstream from the dam (Station 4320000).

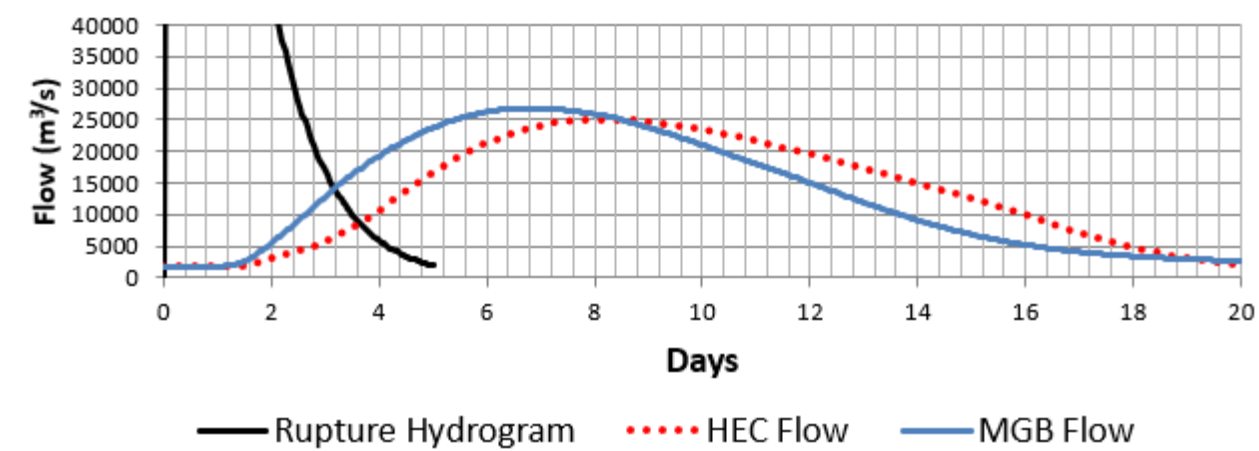

Figure 15. Hydrograms $352 \mathrm{~km}$ downstream from the dam (Station 4420000).

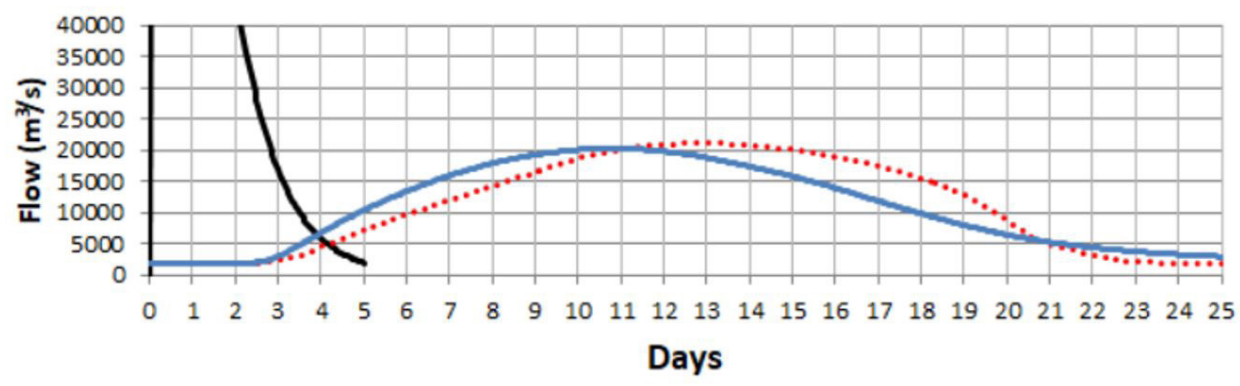

\section{- Rupture Hydrogram $\quad \cdots .$. HEC Flow —MGB Flow}

Figure 16. Hydrograms $542 \mathrm{~km}$ downstream from the dam (Station 4450000).

Table 2. Differences observed among the models.

\begin{tabular}{cccccc}
\hline Station & $\mathbf{4 1 1 3 5 0 0 0 0}$ & $\mathbf{4 2 2 1 0 0 0 0}$ & $\mathbf{4 3 2 0 0 0 0}$ & $\mathbf{4 4 2 0 0 0 0}$ & $\mathbf{4 4 5 0 0 0 0}$ \\
\hline Distance from Dam & $131 \mathrm{~km}$ & $246 \mathrm{~km}$ & $287 \mathrm{~km}$ & $352 \mathrm{~km}$ & $542 \mathrm{~km}$ \\
Flow Peak MGB $\left(\mathrm{m}^{3} / \mathrm{s}\right)$ & 72834 & 38746 & 32062 & 26812 & 20256 \\
Flow Peak Hec $\left(\mathrm{m}^{3} / \mathrm{s}\right)$ & 82211 & 37823 & 30476 & 25069 & 21128 \\
Time Peak MGB (day) & 2.00 & 4.29 & 5.58 & 6.79 & 10.75 \\
Time Peak Hec (day) & 1.83 & 3.96 & 5.96 & $\mathbf{8 . 2 5}$ & 12.88 \\
Flow Peak Diff. (\%) & $\mathbf{1 3} \%$ & $\mathbf{- 2 \%}$ & $\mathbf{- 5 \%}$ & $\mathbf{- 7 \%}$ & $\mathbf{4 \%}$ \\
Time Peak Diff. Tp (\%) & $\mathbf{- 8} \%$ & $\mathbf{- 8} \%$ & $\mathbf{7 \%}$ & $\mathbf{2 1 \%}$ & $\mathbf{2 0} \%$ \\
\hline
\end{tabular}

differences of the propagation model inside the channel) can be considered as additional components of the typical uncertainty existing in studies of dam ruptures, which is directly related to the accuracy of the input data used (Collischonn \& Tucci, 1997; Gallegos et al., 2009; Kim \& Sanders, 2016).
It is known that small variations in the input data (such as reservoir volume, adopted Manning coefficient or ruptured hydrograph form) have different influences on the results regarding the peak flow and peak time for different distances from the dam under analysis (Tschiedel \& Paiva, 2018). The evaluation of the 
errors associated with the use of the MGB-IPH to predict the impacts related to this type of disaster must be carried out in an integrated way to these typical uncertainties.

Many research studies have shown that for sections located at great distances from the dam, the influence (both in peak and peak time) exerted by fluctuations in the Manning values adopted is superior to the uncertainties associated with, for example, the rupture hydrograph or even representation of topography (Collischonn \& Tucci, 1997; Souza, 2016). For example, usual variations in the adopted Manning coefficient may exert uncertainties of about $25 \%$ to $60 \%$ in the peak time and $10 \%$ to $70 \%$ in the peak flow in distant sections of the dam, while variations involving the rupture hydrograph can have an influence of about $20 \%$ and $5 \%$, respectively, for these parameters (Begnudelli \& Sanders, 2007; Regasa \& Jabir, 2019; Tschiedel \& Paiva, 2018).

Considering the existence of these uncertainties in the dam breaking simulation process, the definition of probabilistic flood boundaries (Federal Guidelines for Dam Safety, 2014; Lara, 2016) is growing, since their objective is to insert the uncertainties regarding the use of input data into the results obtained.

As observed in Table 2, the values for the simulated peak flows in the MGB model were very close to the simulated values in the Hec-Ras reference model. And consequently, this generated an also very close coupling between the simulated flood spots, as well as the critical success rate and the normalized depth error.
In Figure 17 a map showing these results is presented globally for the study area and also locally for some regions. The value reached for the Critical Success Index was $84.2 \%$, which indicates an good representation of the flood spot by the MGB-IPH model.

Likewise, Figure 18 presents the map resulting from the evaluation of the normalized mean error for the simulated depth. In this sense, there is a median difference of 2.11 meters in depth between both models, associated with an error of fewer than 3 meters in $70 \%$ of the area and less than 1 meter in $23 \%$ of the flood area.

These pixel-to-pixel depth differences were finally compared to the depth obtained from the Hec-Ras (Benchmark) model, generating the map in Figure 19, which shows the representativeness of the depth error versus the calculated depths by Hec-Ras. In this figure, it is observed that the performance of the MGB -IPH model in the depth estimation had a median difference of $23 \%$, for the whole simulated area.

Finally, the results obtained in this work allowed observing that the use of the MGB-IPH to predict the propagation of a rupture hydrograph along the downstream valley of the dam of the Três Marias HPP is configured as having a high potential of representation both of the peak flows and peak time as well as of the flood spot generated, for the evaluated sections and conditions adopted.

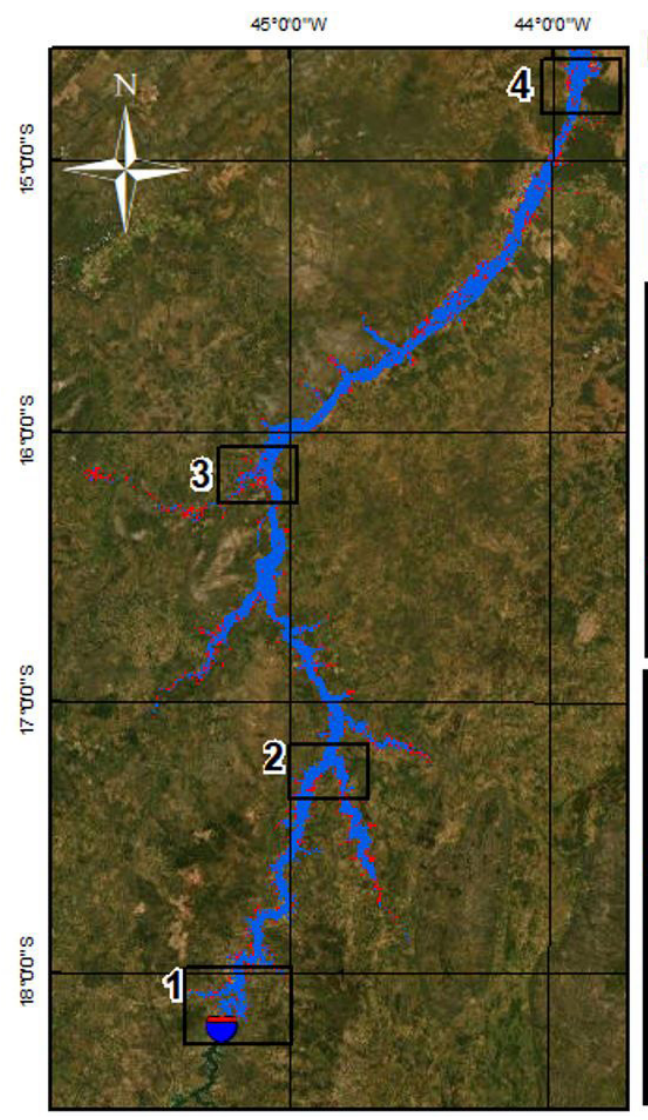

\section{Legend \\ - 3 Marias Dam \\ Wrong Prediction \\ Right Prediction}
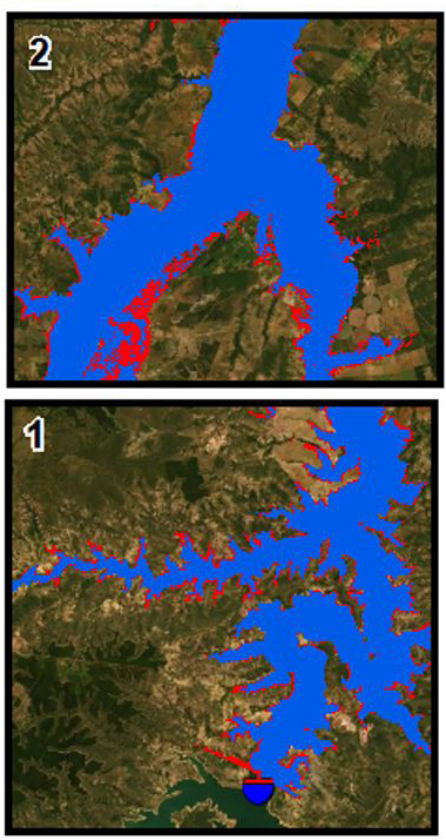

\section{Map Data}

Geodetic Reference System

WGS 1984

Map Scale: $1: 2,200,000$

Detail Scale: $1: 350,000$
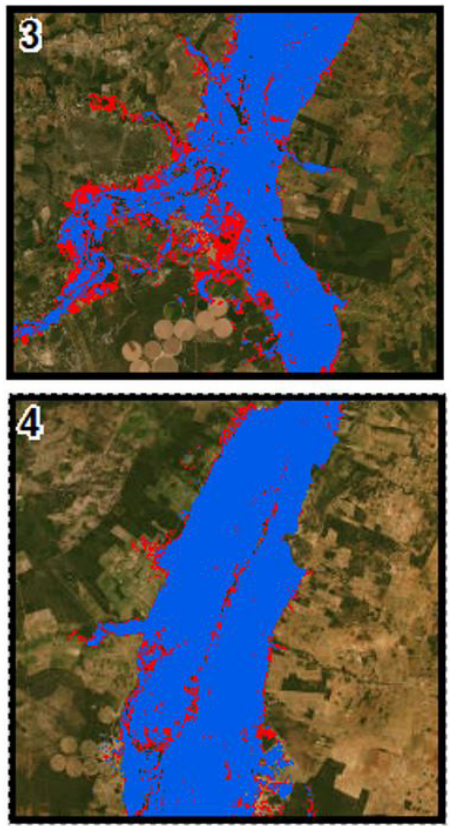

Figure 17. MGB model set-up index in relation to Hec-RAS (benchmark). In these figure, the numbers 1, 2, 3 and 4 represent areas where the results are exposed in more detail. 


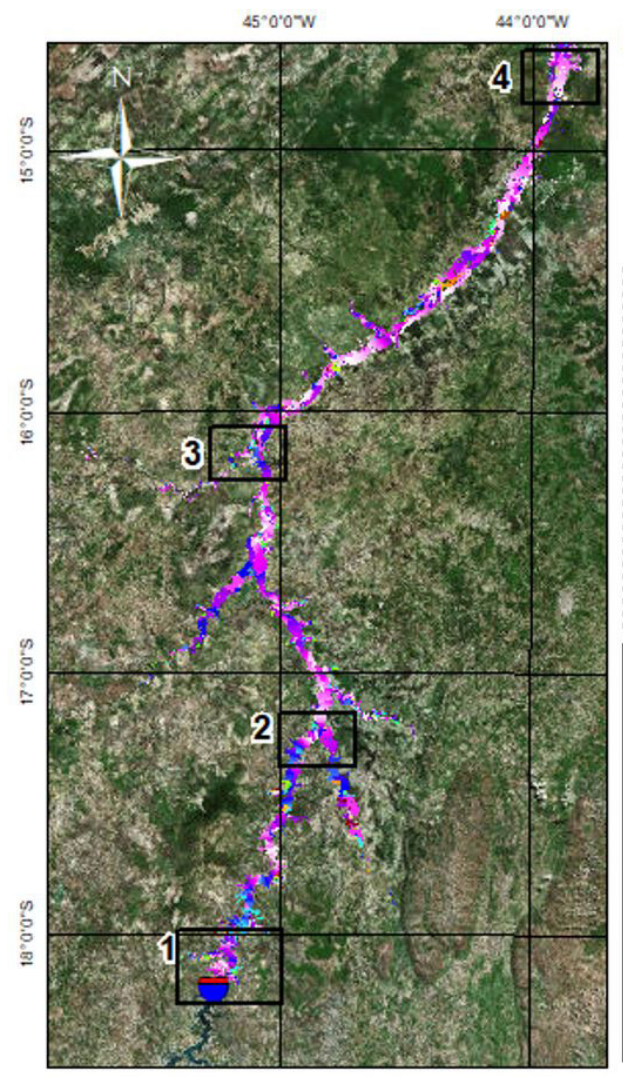

\section{Legend \\ - 3 Marias Dam \\ Error (m) \\ Max $: 25 \mathrm{~m}$}

\section{Map Data}

Geodetic Reference System WGS 1984

Map Scale: 1:2,200,000

Detail Scale: $1: 350,000$
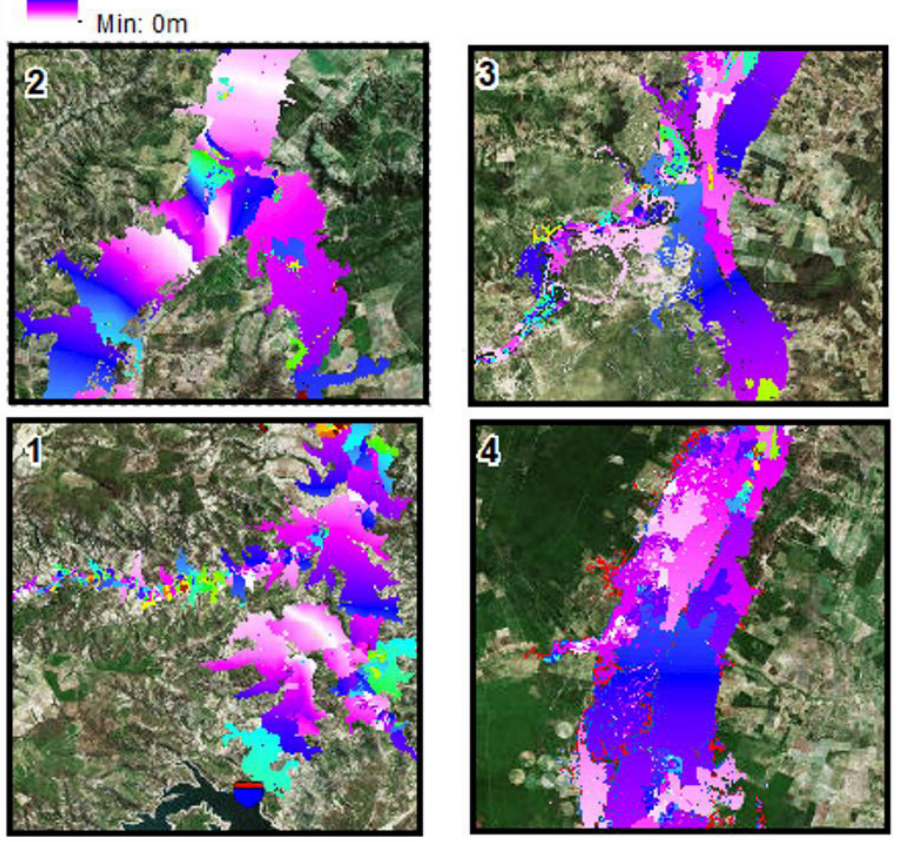

Figure 18. Depth error of the MGB model compared to the Hec-RAS (benchmark). In these figure, the numbers 1,2, 3 and 4 represent areas where the results are exposed in more detail.

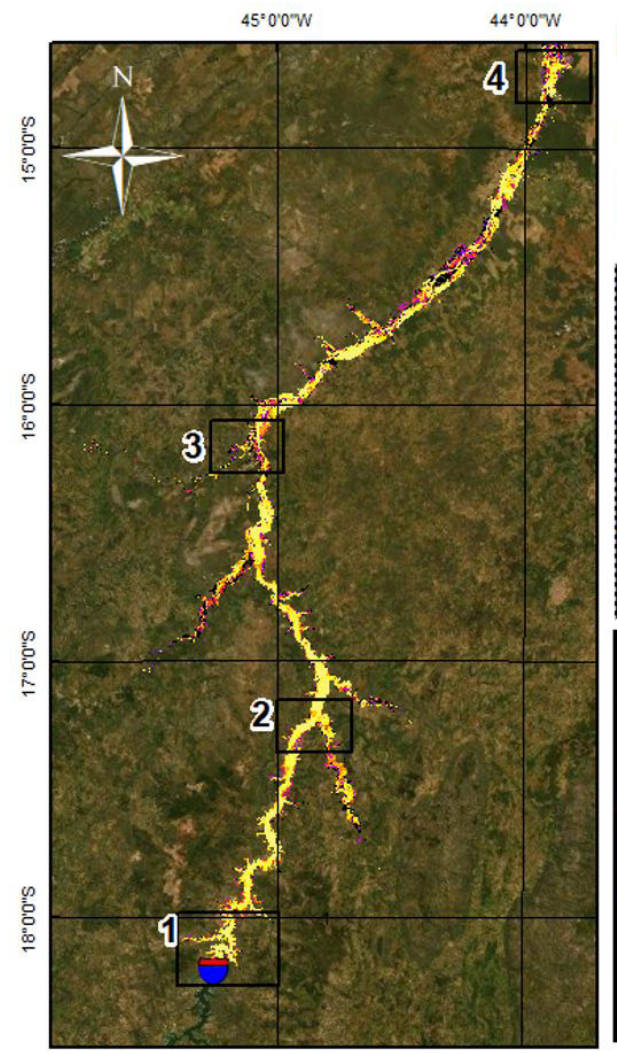

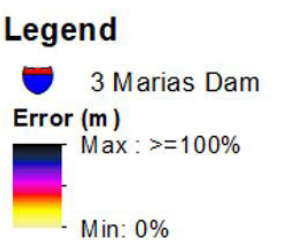
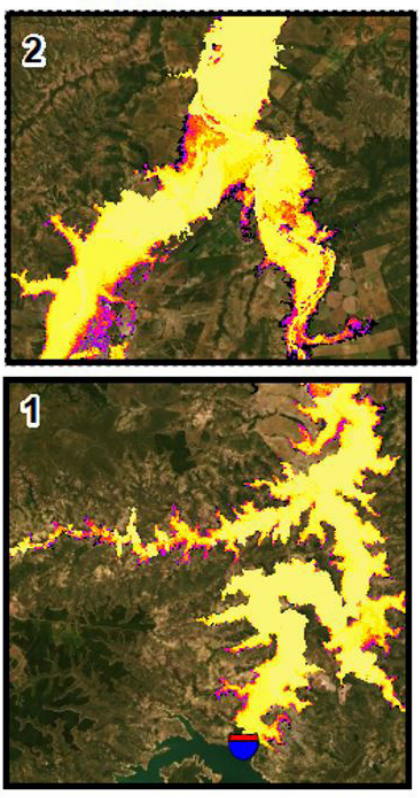

\section{Map Data}

Geodetic Reference System WGS 1984

Map Scale: 1:2,200,000

Detail Scale: $1: 350,000$
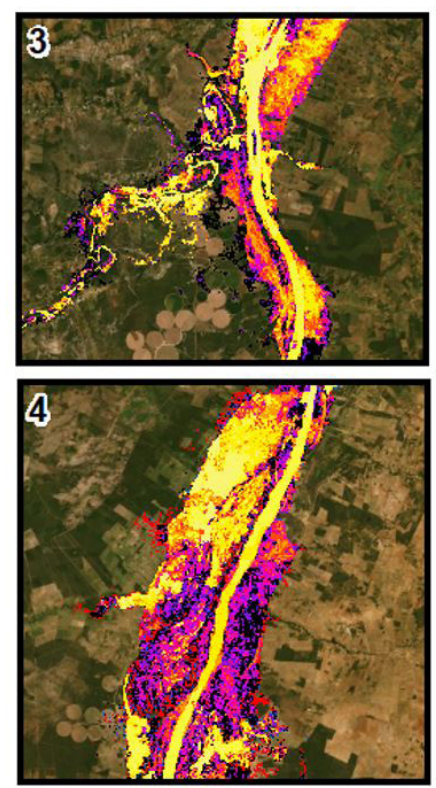

Figure 19. Relative Depth Error of the MGB model compared to Hec-RAS (benchmark). In these figure, the numbers 1, 2, 3 and 4 represent areas where the results are exposed in more detail. 


\section{CONCLUSIONS}

Considering the need for disaster management agencies to estimate the impacts associated with possible failure of large dams, and also considering the lack of non-simplified methodologies that can be applied at scales that exceed the basin scale, this study showed that the use of Large Scale Hydrological Models associated with inertial propagation model to simulate flood waves caused by a dam break process has the potential to contribute to the management of these disasters on a national or continental scale. Thus, from this study:

- The use of the MGB-IPH propagation module to propagate flows along the main channel has a potential to predict important variables in dam break analyses, since the errors obtained in this study have been shown to be low magnitude (less than 20\%) or of the same order as uncertainties typically associated with dam breaks;

- The use of the propagation module of MGB-IPH to predict areas flooded due to dam rupture tends to overestimate the peak flow of the rupture hydrograph for the conditions presented in this study, being configured as conservative in the Emergency Action, mainly regarding the definition of Associated Potential Damage;

- The main limitations of the use of the propagation module of MGB-IPH to predict the propagation of a dam failure flood wave are associated with non-propagation of the hydrograph in the floodplain. This simplification tends to generate an overestimation of the potentially flooded area, favoring the safety of its application as a subsidy to Emergency Action Plans. On the other hand, it is emphasized that the peak and base times estimated by MGB-IPH are much higher than they would have been if propagation was considered in the floodplain. Considering these limitations, caution should be exercised if the information on hydrograph propagation times is used in studies associated with the definition of, for example, Associated Potential Damage of dams.

It is also noted that the differences obtained in the hydrographs, and consequently in the flooded areas, not only reflect the changes made in the flow propagation scheme (Inertial x Saint Venant), but also in the structural and topological architecture of the model within the main channel and on the floodplains.

Considering only the main channel, where the hydrograph propagates, whereas Hec-Ras calculates water surface elevation and flow from one cross section to the next, the MGB calculates the downstream flow and the water surface elevation value for each river reach (in this work defined in $10 \mathrm{~km}$ ).

Likewise, there are also structural and topological differences in the floodplain. Even though the consideration of the floodplain is similar in both models, since there is no propagation in these areas, it is emphasized that the calculation of the water surface elevation (and consequently the flooded area) is performed in each cross section in Hec-Ras, while in the MGB this calculation is performed considering the hypsometric curve of each unit catchment discretized and the volume that exceeds the banks of the river reach in each calculation interval.
However, if on the one hand it is not possible to measure what is the real impact of each of the different approaches on the resulting hydrographs, it should be noted that the sum of these two is associated with very similar results.

Despite this, another conclusion of this study is associated with the provision of first indications that the inertial propagation (which neglects only the term of advective inertia of the saint venant equations) may be appropriate to propagate abrupt hydrographs resulting from the rupture of dams, for certain conditions. This observation seems to be promising since the hydrological community has in recent years adopted this type of solution in Large Scale Hydrological Models widely used in the management of water resources (Yamazaki et al., 2013; Bates et al., 2010; Schumann et al., 2013; Getirana et al., 2017). Finally, it is understood that MGB-IPH was adequate to simulate the propagation of the adopted rupture hydrograph, mainly taking into account the quality of the topographic data used, which tend to represent the downstream plains well. Therefore, considering the consolidation of the MGB-IPH model on a continental scale (Siqueira et al., 2018a), there is the motivation to use this model in the context of the prediction of the joint impact associated with the rupture of large dams in the continent or in other scales. In this sense, it is important to note that, pending the

consolidation of hydrological models of hyper resolution (Wood et al., 2011), the hydrological community still faces the tradeoff between the application of models at different scales and the resolution of the input (and hence output) data. While a better spatial resolution of input data is generally associated with local and regional models, large-scale models use input data with a lower resolution, which may be associated with a possible loss of hydrological representativeness in stretches of interest (Fleischmann et al., 2019b). On the other hand, even if the accuracy of the exit data can be partially sacrificed in large-scale models, the fast generation of downstream dam failure impacts seems to be relevant... In addition, the application of this method on a large scale seems to open an opportunity to carry out dam break analyses in an integrated manner in large territories, which may result in new conceptions about this type of problem.

\section{REFERENCES}

Agência Nacional de Águas - ANA. (2016a). Relatório de segurança de barragens 2015. Brasília: Superintendência de Regulação.

Agência Nacional de Águas - ANA. (2016b). Manual do empreendedor sobre segurança de barragens: guia de orientação e formulários do Plano de Ação Emergencial - PAE. Brasília.

Agência Nacional de Águas - ANA. (2018). Relatório de segurança de barragens 2017. Brasília: Superintendência de Regulação.

Agência Nacional de Águas - ANA. (2019a). Massas d'água (Espelhos D'água). Brasília: Superintendência de Regulação. Retrieved in 2019, April 12, from http:/ / metadados.ana.gov.br/geonetwork/ $\mathrm{srv} / \mathrm{pt} / \mathrm{main}$.home 
Agência Nacional de Águas - ANA. (2019b). Sistema de Acompanbamento de Reservatórios. Brasília. Retrieved in 2019, January 12, from http:/ / sar.ana.gov.br/MedicaoSin

Agência Nacional de Águas - ANA. (2019c). Portal Hidroweb. Brasília. Retrieved in 2019, January 12, from http://www.snirh. gov.br/hidroweb/publico/apresentacao.jsf

Ahmadian, R., Falconer, R. A., \& Wicks, J. (2018). Benchmarking of flood inundation extent using various dynamically linked one-and two-dimensional approaches. Journal of Flood Risk Management, 11, S314-S328. http://dx.doi.org/10.1111/jfr3.12208.

Almeida, G. A. M., \& Bates, P. (2013). Applicability of the local inertial approximation of the shallow water equations to flood modeling. Water Resources Research, 49(8), 4833-4844. http:/ /dx.doi. org/10.1002/wrcr.20366.

Alves, M. E. P., Fan, F. M., \& Fleischmann, A. S. (2019). Simulação de rompimento de barragens em cascata com o modelo MGB. In Anais do XXIII Simpósio Brasileiro de Recursos Hídricos. Porto Alegre: ABRH.

Barfield, B. J., Warner, R. C., \& Haan, C. T. (1981). Applied bydrology and sedimentology for disturbed areas (pp. 104-108). Stillwater: Oklahoma Technical Press.

Bates, P. D., Horritt, M. S., \& Fewtrell, T. J. (2010). A simple inertial formulation of the shallow water equations for efficient two-dimensional flood inundation modelling. Journal of Hydrology, 387(1-2), 33-45. http://dx.doi.org/10.1016/j.jhydrol.2010.03.027.

Bates, P. D., Neal, J., Sampson, C., Smith, A., \& Trigg, M. (2018). Progress toward hyperresolution models of global flood hazard. In G. Michel (Ed.), Risk modeling for hazards and disasters (pp. 211232). Amsterdam: Elsevier. http://dx.doi.org/10.1016/B978-012-804071-3.00009-4.

Begnudelli, L., \& Sanders, B. F. (2007). Simulation of the St. Francis Dam-Break Flood. Journal of Engineering Mechanics, 133(11), 1200-1212. http://dx.doi.org/10.1061/(ASCE)0733-9399(2007)133:11(1200).

Benas, N., Chrysoulakis, N., Christakis, N., Kossioris, G., \& Plexousakis, M. (2014). WRF input parameter updates based on recent and long-term satellite observations. In Proceedings of the 12th International Conference of Meteorology, Climatology and Physics of the Atmosphere (pp. 28-31). Greece: Crete University Press.

Bhandari, M. (2017). One-Dimensional (1D) \& Two-Dimensional (2D) dam break analysis and comparison of different breaching parameters using HEC-RAS. Carbondale: Southern Illinois University.

Bhola, P. K., Nair, B. B., Leandro, J., Rao, S. N., \& Disse, M. (2018). Flood inundation forecasts using validation data generated with the assistance of computer vision. Journal of Hydroinformatics, 21(2), 1-17.

Brasil, L. S. S. (2005). Utilização de modelagens uni e bidimensional para a propagação de onda de cheia proveniente de ruptura hipotética de barragem. Estudo de caso: Barragem de Rio de Pedras - MG (Dissertação de mestrado). Programa de Pós-graduação em Saneamento, Meio
Ambiente e Recursos Hídricos, Universidade Federal de Minas Gerais, Belo Horizonte, MG.

Brasil. (2010, 20 de setembro). Lei no 12.334, de 20 de setembro de 2010. Estabelece a Política Nacional de Segurança de Barragens destinadas à acumulação de água para quaisquer usos, à disposição final ou temporária de rejeitos e à acumulação de resíduos industriais, cria o Sistema Nacional de Informações sobre Segurança de Barragens e altera a redação do art. 35 da Lei no 9.433 , de 8 de janeiro de 1997, e do art. $4^{\circ}$ da Lei no 9.984. Diário Oficial [da] República Federativa do Brasil, Brasília.

Brasil. Conselho Nacional de Recursos Hídricos - CNRH. (2012, 4 de setembro). Resolução nº143 de 10 de Julho de 2012. Estabelece critérios gerais de classificação de barragens por categoria de risco, dano potencial associado e pelo volume do reservatório, em atendimento ao art. $7^{\circ}$ da Lei ${ }^{\circ} 12.334$, de 20 de setembro de 2010. Diário Oficial [da] República Federativa do Brasil, Brasília.

Bravo, J. M., Collischonn, W., Pilar, J., \& Tucci, C. E. M. (2006). Otimização de regras de operação de reservatórios utilizando um algoritmo evolutivo. In Anais do I Simpósio de Recursos Hídricos do Sul-Sudeste. Curitiba: ABRH.

Collischonn, W., \& Tucci, C. E. M. (1997). Análise do rompimento hipotético da barragem de Ernestina. Revista Brasileira de Recursos Hidricos, 2(2), 191-206. http://dx.doi.org/10.21168/rbrh.v2n2. p191-206.

Collischonn, W., Allasia, D., Silva, B. C., \& Tucci, C. M. (2007). The MGB-IPH model for large-scale rainfall: runoff modelling. Hydrological Sciences Journal, 52(5), 878-895. http://dx.doi.org/10.1623/ hysj.52.5.878.

Cruz, J. F. (2007). Reavaliação da segurança da barragem de terra da usina bidrelétrica do Piau (Dissertação de mestrado). Universidade Federal de Ouro Preto, Ouro Preto.

Emerton, R. E., Stephens, E. M., Pappenberger, F., Pagano, T. C., Weerts, A. H., Wood, A. W., Salamon, P., Brown, J. D., Hjerdt, N., Donnelly, C., Baugh, C. A., \& Cloke, H. L. (2016). Continental and global scale flood forecasting systems. WIREs. Water, 3(3), 391-418. http://dx.doi.org/10.1002/wat2.1137.

Fan, F. M., Collischonn, W., Meller, A., \& Botelho, L. C. M. (2014b). Ensemble streamflow forecasting experiments in a tropical basin: the São Francisco river case study. Journal of Hydrology, 519, 29062919. http://dx.doi.org/10.1016/j.jhydrol.2014.04.038.

Fan, F. M., Pontes, P., Paiva, R., \& Collischonn, W. (2014a). Avaliação de um método de propagação de cheias em rios com aproximação inercial das equações de Saint-Venant. Revista Brasileira de Recursos Hídricos, 19(4), 137-147. http://dx.doi.org/10.21168/ rbrh.v19n4.p137-147.

Farr, T. G., Rosen, P. A., Caro, E., Crippen, R., Duren, R., Hensley, S., Kobrick, M., Paller, M., Rodriguez, E., Roth, L., Seal, D., Shaffer, S., Shimada, J., Umland, J., Werner, M., Oskin, M., Burbank, D., \& Alsdorf, D. (2007). The Shuttle Radar Topography 
Mission. Reviews of Geophysics, 45(2), RG2004. http://dx.doi. org/10.1029/2005RG000183.

Federal Guidelines for Dam Safety - FERC. (2014). Dam breach analysis. USA: FERC.

Ferla, R. (2018). Metodologia simplificada para análise de aspectos hidráulicos em rompimento de barragens (Dissertação de mestrado). Programa de Pós-graduação em Recursos Hídricos e Saneamento Ambiental, Universidade Federal do Rio Grande do Sul, Porto Alegre.

Ferla, R., Priebe, P. S., Novakoski, C. K., Hampe, R. F., Saliba, A. P. M., Teixeira, E. D., \& Marques, M. G. (2017). Utilização de diferentes equações empíricas na previsão de características de inundação proveniente do rompimento de barragens. In Anais do Simpósio de Hidráulica e Recursos Hídricos dos Países de Lingua Oficial Portuguesa. Porto, Portugal: APRH.

Fleischmann, A. S., Collischonn, W., \& Paiva, R. C. D. (2019a). Estimating design hydrographs at the basin scale: from event-based to continuous hydrological simulation. Revista Brasileira de Recursos Hídricos, 24, 15. http://dx.doi.org/10.1590/2318-0331.241920180109.

Fleischmann, A., Paiva, R., \& Collischonn, W. (2019b). Can regional to continental river hydrodynamic models be locally relevant? A cross-scale comparison. Journal of Hydrology, 3, 100027.

Fleischmann, A., Siqueira, V., Paris, A., Collischonn, W., Paiva, R., Pontes, P., Crétaux, J.-F., Bergé-Nguyen, M., Biancamaria, S., Gosset, M., Calmant, S., \& Tanimoun, B. (2018). Modelling hydrologic and hydrodynamic processes in basins with large semiarid wetlands. Journal of Hydrology, 561, 943-959. http://dx.doi. org/10.1016/j.jhydrol.2018.04.041.

Froehlich, D. (1995a). Embankment dam breach parameters revisited. In Proceedings of the 1995 ASCE Conference on Water Resorce Engineering (pp. 887-891). Texas: ASCE.

Froehlich, D. (1995b). Peak outflow from breached embankment dam. Journal of Water Resources Planning and Management, 121(1), 9097. http:/ /dx.doi.org/10.1061/(ASCE)0733-9496(1995)121:1(90).

Froehlich, D. (2008). Embankment dam breach parameters and their uncertainties. Journal of Hydraulic Engineering, 134(12), 1708-1721. http://dx.doi.org/10.1061/(ASCE)0733-9429(2008)134:12(1708).

Froehlich, D. (2016). Predicting peak discharge from gradually breached embankment dam. Journal of Hydrologic Engineering, 21(11), 04016041. http://dx.doi.org/10.1061/(ASCE)HE.19435584.0001424 .

Gallegos, H. A., Schubert, J. E., \& Sanders, B. F. (2009). Twodimensional, high-resolution modeling of urban dam-break flooding: a case study of Baldwin Hills, California. Advances in Water Resources, 32(8), 1323-1335. http://dx.doi.org/10.1016/j. advwatres.2009.05.008.

George, A. C., \& Nair, B. T. (2015). Dam break analysis using BOSS DAMBRK. Aquatic Procedia, 4, 853-860. http://dx.doi. org/10.1016/j.aqpro.2015.02.107.
Getirana, A. C. V., \& Paiva, R. C. D. (2013). Mapping large-scale river flow hydraulics in the Amazon Basin. Water Resources Research, 49(5), 2437-2445. http://dx.doi.org/10.1002/wrcr.20212.

Getirana, A., Peters-Lidard, C., Rodell, M., \& Bates, P. D. (2017). Trade-off between cost and accuracy in large-scale surface water dynamic modeling. Water Resources Research, 53(6), 4942-4955. PMid:30078915. http://dx.doi.org/10.1002/2017WR020519.

Gharbi, M. M., Soualmia, A., Dartus, D., \& Masbernat, L. (2016). Comparison of 1D and 2D hydraulic models for floods simulation on the Medjerda Riverin Tunisia. Journal of Materials and Environmental Science, 7(8), 3017-3026.

Gonçalves, R. C. D. (2018). Análise de metodologias para classificação quanto ao Dano Potencial Associado em Barragens (Monografia de projeto final). Departamento de Engenharia Civil e Ambiental, Universidade de Brasília, Brasília.

Hariri-Ardebili, M. A. (2018). Risk, Reliability, Resilience (R3) and beyond in dam engineering: a state-of-the-art review. International Journal of Disaster Risk Reduction, 31, 806-831. http://dx.doi. org/10.1016/j.ijdrr.2018.07.024.

Hoch, J. M., Neal, J. C., Baart, F., Van Beek, R., Winsemius, H. C., Bates, P. D., \& Bierkens, M. F. P. (2017). GLOFRIM v1.0: a globally applicable computational framework for integrated hydrologicalhydrodynamic modelling. Geoscientific Model Development, 10(10), 3913-3929. http://dx.doi.org/10.5194/gmd-10-3913-2017.

International Commission on Large Dams - ICOLD. (2018). World register: general synthesis. Retrieved in 2018, December 12, from https:/ / www.icold-cigb.org/GB/world_register/general_synthesis.asp

Jung, C.-G., \& Kim, S.-J. (2017). Comparison of the damaged area caused by an agricultural dam-break flood wave using HEC-RAS and UAV Surveying. Agricultural Sciences, 08(10), 1089-1104. http:/ / dx.doi.org/10.4236/as.2017.810079.

Kim, B., \& Sanders, B. F. (2016). Dam-break flood model uncertainty assessment: case study of extreme flooding with multiple dam failures in Gangneung, South Korea. Journal of Hydraulic Engineering, 142(5), 05016002. http://dx.doi.org/10.1061/(ASCE)HY.19437900.0001097.

Kuhlkamp, J. F. (2016). Análise do efeito em cascata da propagação da onda de cheia gerada pelo rompimento hipotético de uma das barragens existentes no Rio Irani - SC (Monografia). Universidade Federal de Santa Catarina, Florianópolis, SC.

Lara, P. G. (2016). Metodologia Probabilística de previsão de brecha de ruptura de barragens (Dissertação de mestrado). Programa de Pósgraduação em Engenharia Ambiental, Universidade Federal de Santa Catarina, Florianópolis.

Lauriano, A. W. (2009). Estudo de ruptura da barragem de funil: comparação entre os modelos FLDWAV e HEC-RAS (Dissertação de mestrado). Programa de Pós-graduação em Saneamento, Meio Ambiente e Recursos Hídricos, Universidade Federal de Minas Gerais, Belo Horizonte. 
Lea, D., Yeonsu, K., \& Hyunuk, A. (2019). Case study of HECRAS 1D-2D coupling simulation: 2002 Baeksan flood event in Korea. Water (Basel), 11(10), 2048. http://dx.doi.org/10.3390/ w11102048.

Lehner, B., Liermann, C. R., Revenga, C., Vörösmarty, C., Fekete, B., Crouzet, P., Döll, P., Endejan, M., Frenken, K., Magome, J., Nilsson, C., Robertson, J. C., Rödel, R., Sindorf, N., \& Wisser, D. (2011). Global Reservoir and Dam (GRanD) database: technical documentation. Version 1.1. Retrieved in 2019, August 29, from http://www.gwsp.org/products/grand-database.html

Leon, A. S., \& Goodell, C. (2016). Controlling HEC-RAS using MATLAB. Environmental Modelling \& Software, 84, 339-348. http:/ / dx.doi.org/10.1016/j.envsoft.2016.06.026.

Lindsay, J. B. (2016). The practice of DEM stream burning revisited. Earth Surface Processes and Landforms, 41 (5), 658-668. http:/ / dx.doi. org/10.1002/esp.3888.

Liu, Z., Merwade, V., \& Jafarzadegan, K. (2019). Investigating the role of model structure and surface roughness in generating flood inundation extents using 1D and 2D hydraulic models. Journal of Flood Risk Management, 12(1), e12347. http://dx.doi. org/10.1111/jfr3.12347.

Mao, J., Wang, S., Ni, J., Xi, C., \& Wang, J. (2017). Management system for dam-break hazard mapping in a complex basin environment. International Journal of Geo-Information, 6(6), 162. http://dx.doi.org/10.3390/ijgi6060162.

Martins, R., Leandro, J., \& Djordjević, S. (2016). Analytical solution of the classical dam-break problem for the gravity wave-model equations. Journal of Hydraulic Engineering, 142(5), 06016003. http:/ / dx.doi.org/10.1061/(ASCE)HY.1943-7900.0001121.

Mascarenhas, F. C. B. (1990). Modelação matemática de ondas provocadas por ruptura de barragens (Tese de doutorado ). Universidade Federal do Rio de Janeiro, Rio de Janeiro.

Mason, D. C., Trigg, M., Garcia-Pintado, J., Cloke, H. L., Neal, J. C., \& Bates, P. D. (2016). Improving the TanDEM-X Digital Elevation Model for flood modelling using flood extents from Synthetic Aperture Radar images. Remote Sensing of Environment, 173, 15-28. http://dx.doi.org/10.1016/j.rse.2015.11.018.

Melo, J., Araujo, L., Oliveira, M. M., Martins, T., Pinto, M., \& Freitas, P. (2015). Hazard potential classification of dams using a simplified methodology. In Proceedings of the 2nd International Dam World Conference. Lisbon, Portugal: IBRACON.

Operador Nacional do Sistema Elétrico - ONS. (2009). Previsão de vazões diárias ao reservatório de Três Marias usando a técnica de redes neurais. Brasília: ONS. Retrieved in 2019, August 29, from https:// www2.aneel.gov.br/aplicacoes/consulta_publica/documentos/ NT_ONS-051_Revis\%C3\%A30\%201.pdf

Paiva, R. C. D., Buarque, D. C., Collischonn, W., Bonnet, M.-P., Frappart, F., Calmant, S., \& Mendes, C. A. B. (2013). Large-scale hydrologic and hydrodynamic modeling of the Amazon River basin. Water Resources Research, 49(3), 1226-1243. http://dx.doi. org/10.1002/wrcr.20067.

Paiva, R. C. D., Collischonn, W., \& Tucci, C. E. M. (2011). Large scale hydrologic and hydrodynamic modeling using limited data and a GIS based approach. Journal of Hydrology, 406(3-4), 170-181. http://dx.doi.org/10.1016/j.jhydrol.2011.06.007.

Patel, D. P., Ramirez, J. A., Srivastava, P. K., Bray, M., \& Han, D. (2017). Assessment of flood inundation mapping of Surat city by coupled 1D / 2D hydrodynamic modeling: a case. Natural Hazards, 89(1), 93-130. http://dx.doi.org/10.1007/s11069-017-2956-6.

Pereira, C. E., Viseu, M. T., Melo, J. F., Martins, T., Salla, M. R., \& Mota, K. R. R. (2017). Comparação entre modelos simplificados e o modelo HEC-RAS no estudo de áreas de inundação para o caso de Minas Gerais, Brasil. Recursos Hídricos, 38(1), 75-90. http:/ / dx.doi.org/10.5894/rh38n1-cti3.

Peter, S. J. (2017). Dam break analysis under uncertainty (Thesis). ETH Zurich, Zurich, Switzerland.

Petry, A., Laus, F., Anderáos, A., \& Bomfim, M. (2018). Classificação de barragens quanto ao dano potencial associado: a experiência da Agência Nacional de Águas. In Anais da $3^{a}$ Conferência Internacional DAM World 2018. Foz do Iguaçu: IBRACON.

Pierce, M., Thornton, C. I., \& Abt, S. R. (2010). Predicting peak outflow from breached embankment dams. Journal of Hydrologic Engineering, 15(5), 338-349. http://dx.doi.org/10.1061/(ASCE) HE.1943-5584.0000197.

Pontes, P. R. M., \& Collischonn, W. (2016). O modelo MuskingumCunge-Todini em rios com planície de inundação. Revista Brasileira de Recursos Hídricos, 20(2), 298-309. http://dx.doi.org/10.21168/ rbrh.v20n2.p298-309.

Pontes, P. R. M., Collischonn, W., Fan, F., Paiva, R., \& Buarque, D. (2015). Modelagem hidrológica e hidráulica de grande escala com propagação inercial de vazões. Revista Brasileira de Recursos Hídricos, 20(4), 888-904. http://dx.doi.org/10.21168/rbrh.v20n4.p888-904.

Pontes, P. R. M., Fan, F. M., Fleischmann, A. S., de Paiva, R. C. D., Buarque, D. C., Siqueira, V. A., Jardim, P. F., Sorribas, M. V., \& Collischonn, W. (2017). MGB-IPH model for hydrological and hydraulic simulation of large floodplain river systems coupled with open source GIS. Environmental Modelling \& Software, 94, 1-20. http://dx.doi.org/10.1016/j.envsoft.2017.03.029.

Regasa, M. S., \& Jabir, A. K. (2019). Nashe dam fail and risk analysis. Engineering and Science, 4(1), 12-27. http://dx.doi.org/10.11648/j. es.20190401.12.

Rodriguez, E., Morris, C. S., \& Belz, J. E. (2006). A global assessment of the SRTM performance. Photogrammetric Engineering and Remote Sensing, 72(3), 249-260. http://dx.doi.org/10.14358/PERS.72.3.249.

Saraiva, L. S. (2014). Comparação entre critérios para determinação de bidrogramas de ruptura de barragens (Monografia). Escola de Engenharia, Universidade Federal do Rio Grande do Sul, Porto Alegre, RS. 
Schumann, G. P., Neal, J. C., Voisin, N., Andreadis, K. M., Pappenberger, F., Phanthuwongpakdee, N., Hall, A. C., \& Bates, P. D. (2013). A first large-scale flood inundation forecasting model. Water Resources Research, 49(10), 6248-6257. http:/ /dx.doi. org/10.1002/wrcr.20521.

Seal, D., \& Rogez, F. (2000). SRTM as-flown mission timeline. JPL NASA. Retrieved in 2019, August 29, from http://samadhi.jpl. nasa.gov/srtm

Shustikova, I., Domeneghetti, A., Neal, J. C., Bates, P., \& Castellarin, A. (2019). Comparing 2D capabilities of HEC-RAS and LISFLOOD-FP on complex topography. Hydrological Sciences Journal, 64(14), 1769-1782. http://dx.doi.org/10.1080/0262666 7.2019.1671982.

Siqueira, V. A., Paiva, R. C. D., Fleischmann, A. S., Fan, F. M., Ruhoff, A. L., Pontes, P. R. M., Paris, A., Calmant, S., \& Collischonn, W. (2018a). Toward continental hydrologic: hydrodynamic modeling in South America. Hydrology and Earth System Sciences, 22(9), 48154842. http://dx.doi.org/10.5194/hess-22-4815-2018.

Siqueira, V. A., Paiva, R. C. D., Fleischmann, A. S., Fan, F. M., Ruhoff, A. L., Pontes, P. R. M., Paris, A., Calmant, S., \& Collischonn, W. (2018b). Toward continental hydrologic-hydrodynamic modeling in South America. Hydrology and Earth System Sciences, 22(9), 48154842. http://dx.doi.org/10.5194/hess-22-4815-2018.

Sood, A., \& Smakhtin, V. (2015). Global hydrological models: a review. Hydrological Sciences Journal, 60(4), 549-565. http://dx.doi. org/10.1080/02626667.2014.950580.

Souza, D. H. C. (2016). Análise probabilística e de sensibilidade dos parâmetros de um estudo de rompimento hipotético: Barragem de Terra (Dissertação de mestrado). Faculdade de Engenharia Civil, Arquitetura e Urbanismo, Universidade Estadual de Campinas, Campinas.

Tschiedel, A. F. (2017). Avaliação de incerteras em estudos de rompimento de barragens (Dissertação de mestrado). Programa de Pós-graduação em Recursos Hídricos e Saneamento Ambiental, Instituto de Pesquisas Hidráulicas, Universidade Federal do Rio Grande do Sul, Porto Alegre.

Tschiedel, A. F., Tassinari, L. C. S., Fan, F. M., \& Paiva, R. C. D. (2019). Barragens e rompimentos: compilação histórica nacional e internacional. In Anais do XXIII Simpósio Brasileiro de Recursos Hidricos. Porto Alegre: ABRH.

Tschiedel, A. F., \& Paiva, R. C. D. (2018). Uncertainty assessment in hydrodynamic modeling of floods generated by dam break. Revista Brasileira de Recursos Hidricos, 23, 1-17. http://dx.doi. org/10.1590/2318-0331.231820170074.

US Army Corps of Engineers - USACE. (2014). Using HEC-RAS for dam break studies. Davis, CA: Institute for Water Resources.

US Army Corps of Engineers - USACE. (2016). HEC-RAS river analysis system bydraulic reference manual. Davis, CA: Hydrologic Engineering Center.
Wang, B., Chen, Y., Wu, C., Peng, Y., Song, J., Liu, W., \& Liu, X. (2018). Empirical and semi-analytical models for predicting peak outflows caused by embankment dam failures. Journal of Hydrology, 562, 692-702. http://dx.doi.org/10.1016/j.jhydrol.2018.05.049.

Wang, Y.-J., Qin, C.-Z., \& Zhu, A.-X. (2019). Review on algorithms of dealing with depressions in grid DEM. Annals of GIS, 25(2), 83-97. http://dx.doi.org/10.1080/19475683.2019.1604571.

Wood, E. F., Roundy, J. K., Troy, T. J., Van Beek, L. P. H., Bierkens, M. F. P., Blyth, E., de Roo, A., Döll, P., Ek, M., Famiglietti, J., Gochis, D., Van de Giesen, N., Houser, P., Jaffé, P. R., Kollet, S., Lehner, B., Lettenmaier, D. P., Peters-Lidard, C., Sivapalan, M., Sheffield, J., Wade, A., \& Whitehead, P. (2011). Hyperresolution global land surface modeling: meeting a grand challenge for monitoring Earth's terrestrial water. Water Resources Research, 47(5), 1-10. http://dx.doi.org/10.1029/2010WR010090.

Yamazaki, D., Almeida, G. A. M., \& Bates, P. D. (2013). Improving computational efficiency in global river models by implementing the local inertial flow equation and a vector-based river network map. Water Resources Research, 49(11), 7221-7235. http://dx.doi. org/10.1002/wrcr.20552.

Yan, K., Di Baldassarre, G., Solomatine, D. P., \& Schumann, G. J.-P. (2015). A review of low-cost space-borne data for flood modelling: topography, flood extent and water level. Hydrological Processes, 29(15), 3368-3387. http://dx.doi.org/10.1002/hyp.10449.

You, L., Li, C., Min, X., \& Xiaolei, T. (2012). Review of dambreak research of earth-rock dam combining with dam safety management. Procedia Engineering, 28, 382-388. http://dx.doi. org/10.1016/j.proeng.2012.01.737.

Zarfl, C., Lumsdon, A. E., Berlekamp, J., Tydecks, L., \& Tockner, K. (2015). A global boom in hydropower dam construction. Aquatic Sciences, 77(1), 161-170. http://dx.doi.org/10.1007/ s00027-014-0377-0.

Zhang, L., Peng, M., Chang, D., \& Xu, Y. (2016). Dam failure mechanisms and risk assessment. Hoboken: John Wiley \& Sons. http:/ / dx.doi.org/10.1002/9781118558522.

Zhong, Q., Chen, S., \& Deng, Z. (2018). A simplified physically based model for core dam overtopping breach. Engineering Failure Analysis, 90,141-155. http://dx.doi.org/10.1016/j.engfailanal.2018.03.032.

\section{Authors contributions}

Arthur da Fontoura Tschiedel: Performed the simulation tests and worked on the manuscript writing.

Rodrigo Cauduro Dias de Paiva: Assisted the experimental design delineation and revised the manuscript.

Fernando Mainardi Fan: Assisted the experimental design delineation and revised the manuscript. 